\title{
Density Functional Theory-Inspired Design of Ir/P,S-Catalysts for Asymmetric Hydrogenation of Olefins
}

\author{
Jorge Faiges, Carlota Borràs, Isidro M. Pastor, Oscar Pàmies, Maria Besora,* and Montserrat Diéguez* \\ Cite This: Organometallics 2021, 40, 3424-3435 \\ Read Online
}

ABSTRACT: In silico-based optimization of Ir/P,S-catalysts for the asymmetric hydrogenation of unfunctionalized olefins using (E)-1(but-2-en-2-yl)-4-methoxybenzene as a benchmark olefin has been carried out. DFT calculations revealed that the thioether group has a major role in directing the olefin coordination. This, together with the configuration of the biphenyl phosphite group, has an impact in maximizing the energy gap between the most stable transition states leading to opposite enantiomers. As a result, the optimized catalyst proved to be efficient in the hydrogenation of a range of alkenes with

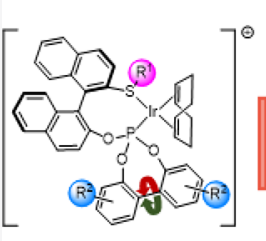

Basic catalyst design for asymmetric hydrogenation the same substitution pattern and olefin geometry as the benchmark olefin, regardless of the presence of functional groups with different coordination abilities (ee values up to 97\%). Appealingly, further modifications at the thioether groups and at the biaryl phosphite moiety allowed the highly enantioselective hydrogenation of olefins with different substitution patterns (e.g., $\alpha, \beta$-unsaturated lactones and lactams, $1,1^{\prime}$-disubstituted enol phosphinates, and cyclic $\beta$ enamides; ee values up to $>99 \%)$.

\section{INTRODUCTION}

The preparation of enantiomerically enriched compounds has become central in the chemical industry in general, and in the pharmaceutical and phytopharmaceutical industry in particular, enabling the production of compounds with increased biological efficacy, less adverse effects, and less costs. ${ }^{1}$ Metalcatalyzed asymmetric hydrogenation with hydrogen gas has postulated itself as a key technology for the preparation of these types of chiral compounds. Their advantages are high atom economy, low catalyst loadings, and operational simplicity. ${ }^{1,2}$ The extensive research dedicated to the asymmetric hydrogenation of prochiral olefins has resulted in catalysts capable of efficiently reducing olefins with very diverse structures. Despite the advances, each catalyst only provides optimal results for a restricted range of olefins. For example, while $\mathrm{Ru} / \mathrm{Rh}$-diphosphines are the most suitable for the hydrogenation of functionalized substrates, ${ }^{3}$ the catalysts of choice for the hydrogenation of unfunctionalized olefins are Ir$\mathrm{P}, \mathrm{N}$ catalysts. ${ }^{4}$ In between the unfunctionalized olefins and the analogues with coordinating functional groups, there is a wide range of interesting substrates with intermediate coordinating properties, such as $\alpha, \beta$-unsaturated esters, lactones, lactams, and ketones, for which Ir-catalysts have been superior to $\mathrm{Rh} /$ Ru-catalysts. ${ }^{4}$ Nevertheless, the effectiveness of these Ircatalysts again depends on the geometry and substitution pattern of the olefin. ${ }^{4}$ The identification of a catalyst useful for substrates with functional groups with varying coordination abilities and with different substitution patterns remains a central task in asymmetric hydrogenation.
The bottleneck in finding the optimal catalyst is the identification of the right family of ligands. ${ }^{5}$ The discovery of an efficient ligand is mostly carried out empirically, ranging from trial-and-error approaches to more or less rational designs based on mechanistic studies. This process has been aided by a variety of procedures for evaluation of catalysts, such as highthroughput experimentation, but still remains costly. ${ }^{5}$ These semi-empirical approaches can reject good ligands that unfortunately deemed not successful during the initial screening not because the ligand was not good but because it was not tested under the right conditions. Nowadays, catalyst discovery is being aided by the advances in DFT computational simulations but its use is mostly focused on justifying exciting catalytic results instead of foreseeing potential uses.

Over the past decade, we have demonstrated that Ir-catalysts modified with chiral $\mathrm{P}$,thioether ligands are good alternatives to the commonly used Ir-P,N catalysts in the asymmetric hydrogenation of olefins without coordinative groups owing to the fact that thioether groups are more stable than oxazolines and generate an additional stereogenic center near to Ir, which confers a different steric environment around the metal center. ${ }^{6}$ Several families of $\mathrm{P}$,thioether ligands synthesized in

Received: July 31, 2021

Published: October 11, 2021 
a few steps from inexpensive sources gave results comparable to the best reported data. We have also shown that their optimization could be aided by DFT calculations. ${ }^{6 c}$ In this article, we go one step further and we first make use of DFT calculations to study in silico the possibilities of new types of $P$,thioether ligands. The findings are then validated experimentally in the laboratory. To speed up the simulation process, the ligand design must limit the number of conformations energetically available of the chelate ring as well as restrain the flexibility at both the thioether and phosphorous moieties. One ligand class especially well suited in limiting the number of conformations of the chelate ring is that containing a chiral $1,1^{\prime}$-binapththalene core (such as BINOL, BINAP....). ${ }^{5(\mathrm{~b})}$ Therefore, we started the calculations with diastereomeric binaphthyl-based phosphite-thioether ligands $\mathbf{L} \mathbf{1}$ and $\mathbf{L 2}$, which contain an easy to compute methyl thioether group and fixed configurations of the biphenyl phosphite moiety (Figure 1). It is to note that this type of
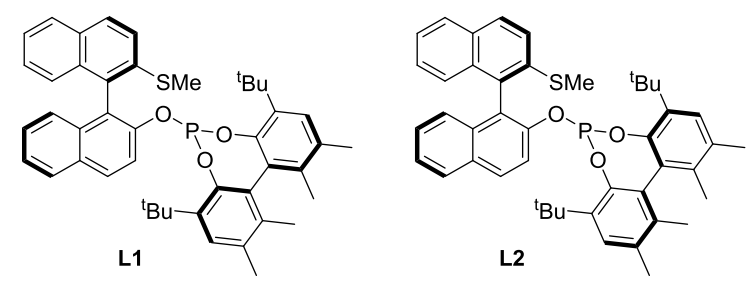

Figure 1. Binaphthyl-based phosphite-thioether ligands L1 and L2.

heterodonor binaphthyl-based $\mathrm{P}$, thioether led to the first applications of $\mathrm{P}, \mathrm{S}$ ligands in asymmetric processes, such as hydroformylation, hydrogenation, and allylic alkylations. ${ }^{7}$ However, the fact that only promising results were reached in allylic alkylation limited further developments, in contrast to the high applicability and success of BINAP-type ligands.

\section{RESULTS AND DISCUSSION}

Theoretical Ligand Design. We initially focused the catalyst design on the Ir-catalyzed asymmetric hydrogenation of unfunctionalized olefins using (E)-1-(but-2-en-2-yl)-4methoxybenzene $\mathbf{S} 1$ as a benchmark olefin. Their reduction is less established than the hydrogenation of functionalized olefins. Most catalysts are still sensitive to the number and nature of substituents, and important olefins still provide suboptimal results. ${ }^{4}$ Mechanistically, the hydrogenation of these types of substrates proceeds via $\mathrm{Ir}^{\mathrm{III}} / \mathrm{Ir}^{\mathrm{V}}$ species as demonstrated both theoretically and experimentally. ${ }^{8}$ The enantioselectivity-determining step is the transfer of the first hydrogen atom to the coordinated alkene. This step, however, can proceed via two different pathways. Usually, the most energetically favorable pathway is the one that involves the migratory insertion of the hydride (Figure 2). However, the

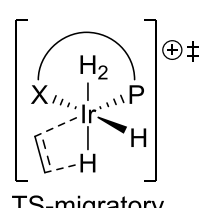

TS-migratory insertion

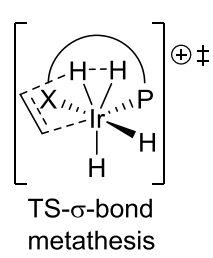

Figure 2. Representation of the transition states for the migratory insertion and $\sigma$-bond metathesis hydrogenation pathways $(X=N, S$, or $\mathrm{O})$. alternative $\sigma$-bond metathesis pathway is also energetically feasible (Figure 2). Thus, we computed all possible transition states (TSs) for the migratory insertion and $\sigma$-bond metathesis pathways with ligands L1 and L2 using S1 as a benchmark unfunctionalized olefin.

Due to the lack of symmetry of ligands $\mathbf{L} \mathbf{1}$ and L2, we had to consider the relative position of the axial hydride and the hydrogen molecule (up or down) as well as the configuration of the coordinated thioether moiety, the face selectivity of coordination of the olefin ( $r e$ and $s i$ ), and the regioselectivity of the hydrogen insertion toward the most and least substituted olefinic carbon atom. In line with previous studies, our calculations indicated that the migratory insertion is more favorable than the $\sigma$-bond metathesis (see the Supporting Information). Table 1 shows the two most stable TSs leading

Table 1. Summary of the Most Favored TSs for the Migratory Insertion with Ir/L1 and Ir/L2 Catalysts with Substrate $S 1^{a}$

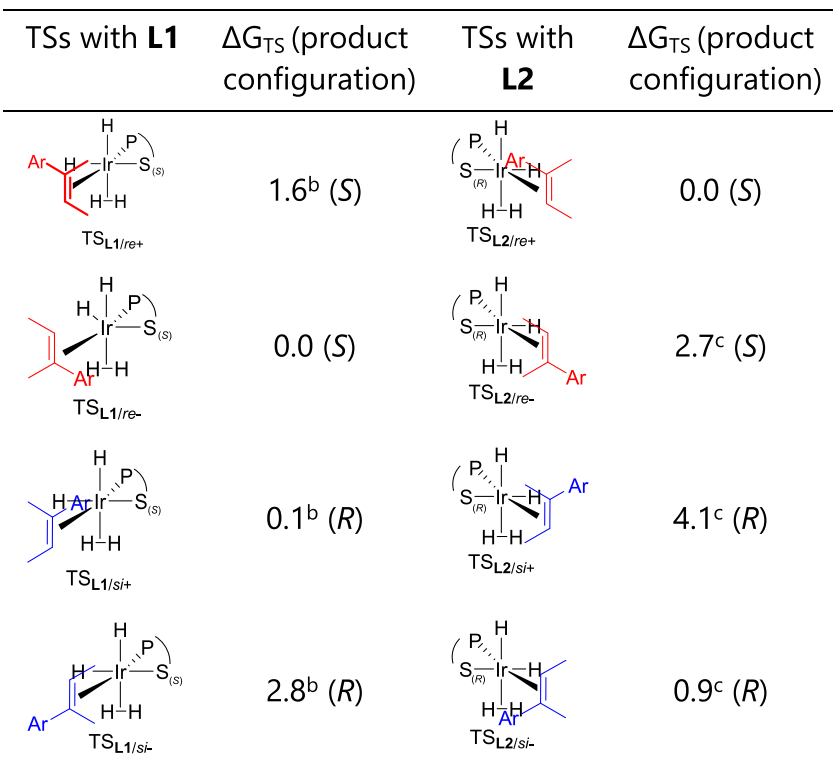

${ }^{a}$ Relative energies in $\mathrm{kcal} / \mathrm{mol}$. The sulfur chirality for each TS is given in parenthesis. The naming of the TSs includes the ligand, the prochiral face olefin coordination ( $r e$ or $s i$ ), and the + symbol to indicate that the MI takes place at the most substituted carbon or the - symbol to indicate that the MI occurs at the less substituted carbon. ${ }^{b}$ Energies relative to that of $\mathrm{TS}_{\mathrm{L} 1 / r e \text {-. }}{ }^{c}$ Energies relative to that of $\mathrm{TS}_{\mathbf{L} 2 / \text { ret }}$.

to enantiomers $R$ and $S$ of the hydrogenated product for each ligand. The simulations also predicted that the catalyst with ligand $\mathbf{L} 2$ should provide higher enantioselectivities than that with L1.

The theoretical results were then validated by synthesizing the corresponding catalyst precursors $[\operatorname{Ir}(\operatorname{cod}) \mathbf{L}] \mathrm{BAr}_{\mathrm{F}}(\mathbf{L}=\mathbf{L} \mathbf{1}$ and L2) and testing them in the hydrogenation of S1 under standard conditions (Scheme 1). ${ }^{6}$ As predicted by the calculations, ligand L2 gave higher enantioselectivity than L1.

In addition, our computational results showed that the most favored TSs for each ligand have the same chirality at the coordinated sulfur atom and the same hydride/hydrogen disposition (Table 1). This finding significantly simplifies the analysis because the ligand disposition is the same in all cases and the TSs only differ on the olefin orientation and on the 
Scheme 1. Asymmetric Hydrogenation of S1 Using [ $\operatorname{Ir}(\operatorname{cod})$ $\mathrm{L}] \mathrm{BAr}_{\mathrm{F}}(\mathrm{L}=\mathrm{L} 1 \text { and } \mathrm{L} 2)^{a}$

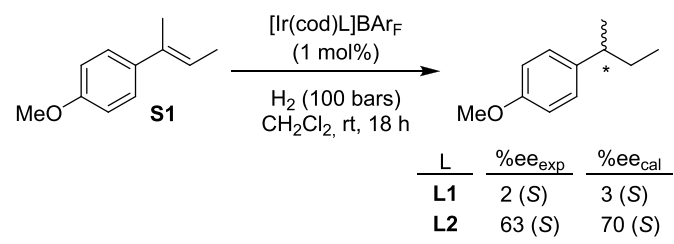

${ }^{a}$ Comparison with the theoretical results.

olefinic carbon in which the migratory insertion takes place. Taking this into account, we developed a model to rationalize the origin of the enantioselectivity induced by each ligand. For that, we used the quantitative quadrant-diagram representation of the molecular system (MolQuO). ${ }^{9}$ To begin with, we studied the system without the olefin to analyze the sterically hindered and free regions of the catalyst (Figure 3). For both ligands, the most occupied quadrant is the one with the thioether substituent. a)

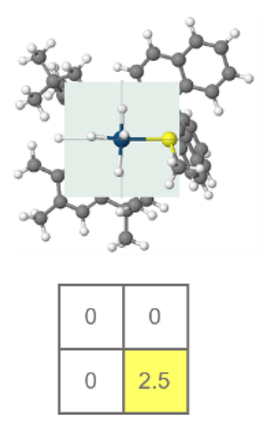

b)

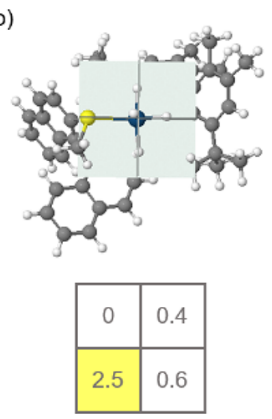

Figure 3. Models of Ir-catalysts with ligands (a) L1 and (b) L2 without the olefin. The partial occupation of each quadrant according to $\mathrm{MolQuO}$ is shown. Note that for each ligand, this analysis was done with the favored hydride/hydrogen disposition.

Then, we evaluated the change in the arrangement of the ligand around the metal center in the most favored TSs of each ligand (Figure 4). Note that this analysis was done taking the geometry of the whole TS, as shown in the figure, but removing the atoms of the olefin in the MolQuO calculation (see Computational Details). For both catalysts, the most occupied quadrant is still the one with the substituent of the thioether moiety. In addition, the less energetic TSs tend to have the most hindered quadrant occupied by the olefinic hydrogen (as one would expect) or the olefinic aryl moiety. This latter result can be explained by the fact that either the planarity of the aryl ring reduces the steric clash with the thioether's methyl or the existence of a $\mathrm{C}-\mathrm{H} \pi$-stacking interaction between the substrate's aryl ring and the methyl of the thioether substituent. These interactions are clearly seen in NCI plot analysis (see the Supporting Information for more details). In this case, the steric constrains seem to be the main reason in the stabilization of TSs with the aryl olefinic moiety at the most occupied quadrant because attractive interactions with the olefinic aryl ring are found in all the possible TSs owing to the aromatic nature of the ligand.

A further analysis of the calculated structures allows us to explain the different enantiocontrol exerted by the complexes with ligands L1 and L2. For that purpose, we should pay attention to the upper right quadrant. For L1, this quadrant is hardly occupied by the ligand without the olefin (Figure 3) but it becomes occupied in the most stable TS ( $\mathrm{TS}_{\mathrm{L} 1 / \text { re-; }}$ Figure 4$)$. This is due to the fact that there is an attraction between the olefinic hydrogen and the ligand, which can be visualized by the reduction of the P-O-C angle of the binaphthyl moiety from $125.7^{\circ}$ (the angle without the olefin) to $122.3^{\circ}$ (Figure $5)$. Note that one would expect the transition state $\mathrm{TS}_{\mathrm{L} 1 / s i+}$ to be the most favorable due to the presence of the olefinic hydrogen at the most sterically hindered quadrant (Figure 4). Although the attraction between the aryl group of the olefin with the ligand still exists (as seen in an NCI plot analysis, see the Supporting Information for more details), to minimize the steric clash, the angle $\mathrm{P}-\mathrm{O}-\mathrm{C}$ in $\mathrm{TS}_{\mathrm{L} 1 / s i+}$ increases to $128.8^{\circ}$ to accommodate the aryl group of the olefin and the $\mathrm{Ir}-\mathrm{P}$ bond gets longer (Figure 5). This distortion makes the $\mathrm{TS}_{\mathrm{L} 1 / s i+}$ less stable than one would a priori expect. As a result $\mathrm{TS}_{\mathrm{L} 1 / s i+}$ and $\mathrm{TS}_{\mathrm{L} 1 / \text { re- }}$ have similar energies. This explains the low enantioselectivity obtained when using ligand $\mathbf{L} \mathbf{1}$.

In contrast to $\mathbf{L} \mathbf{1}$, for $\mathbf{L} \mathbf{2}$, the occupation of the upper right quadrant is similar in the two most stable $\mathrm{TSs}\left(\mathrm{TS}_{\mathrm{L} 2 / \text { ret }}\right.$ and $\mathrm{TS}_{\mathrm{L} 2 / s i-}$, Figure 4) and therefore the interaction between one of the olefinic methyls and the ligand is similar. As a consequence, the energy difference between both TSs can be attributed to the different steric effects when the most hindered quadrant (the lower left quadrant) is occupied by the olefinic hydrogen (for the $\mathrm{TS}_{\mathrm{L} 2 / \text { ret }}$ leading to the $S$ product) or the olefinic aromatic group (for the $\mathrm{TS}_{\mathrm{L} 2 / s i}$ leading to the $R$ product). Therefore, there is a preferred stabilization of the $\mathrm{TS}_{\mathrm{L} 2 / \text { ret }}$ due to the presence of the olefinic hydrogen at the most sterically hindered quadrant. This situation increases the energy gap between the $\mathrm{TS}_{\mathrm{L} 2 / \text { re+ }}$ and $\mathrm{TS}_{\mathrm{L} 2 / s i-}$ and could explain the higher enantiomeric excess achieved with $\mathrm{Ir} / \mathrm{L} 2$ in the $S$ product compared with Ir/L1.

The above results demonstrate the key role of the thioether substituent in the enantiodiscrimination and the importance of the methyl thioether substituent to force the olefinic hydrogen to preferentially occupy the most hindered quadrant. This finding suggests that ligand modifications able to block even further this quadrant would destabilize the TS that places the olefinic aryl group at the most hindered quadrant and therefore would lead to higher enantioselectivities. A simple way to check this was to introduce a bulkier thioether substituent and check by MolQuO how this affected the quadrants' diagram. We considered three thioether substituents L3-L5, and, to simplify the calculations, we studied the three systems without the olefin (Figure 6). As it could be expected, the bulkier the thioether substituent, the more effectively the quadrant is blocked and therefore it should provide higher ee values.

To verify our hypothesis, we prepared two of the three Ircatalyst precursors, containing ligands $\mathrm{L} 3\left(\mathrm{R}={ }^{\mathrm{i}} \mathrm{Pr}\right)$ and $\mathrm{L5}(\mathrm{R}$ $=\mathrm{Cy})$, and applied them in the asymmetric hydrogenation of S1 (Table 2). We also included in this study four new Ircatalyst precursors with analogue ligands L6-L9, which contains a flexible biphenyl phosphite moiety (Table 2) in order to evaluate whether the joint action of the binapththyl ligand backbone and the thioether substituent is able to control the tropoisomerization of the flexible biphenyl phosphite moiety.

In line with the calculated occupancy of the quadrants, the results indicated that enantioselectivities increase as the alkyl groups at the thioether get bulkier: $\mathrm{Me}$ (ligand L2) < ${ }^{\mathrm{i}} \mathrm{Pr}$ (ligand L3) < Cy (ligand L5). 

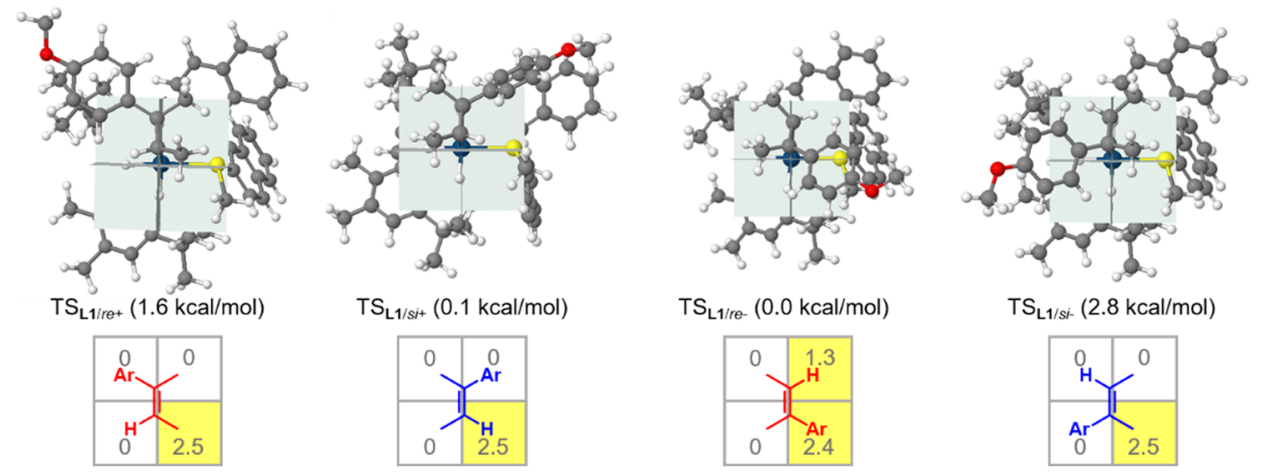

$\operatorname{TS}_{\mathrm{L1} / \mathrm{re}-}(0.0 \mathrm{kcal} / \mathrm{mol})$

$\operatorname{TS}_{\mathrm{L} 1 / \mathrm{si}-}(2.8 \mathrm{kcal} / \mathrm{mol})$
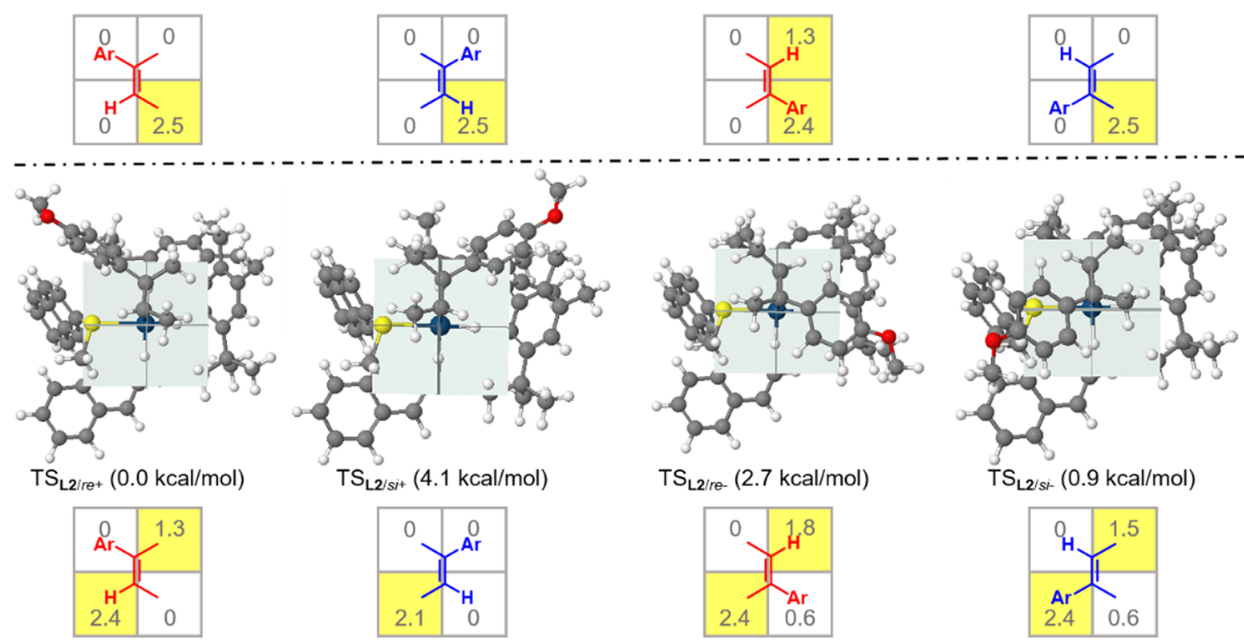

Figure 4. Models of the most favored transition states for Ir-complexes with ligands L1 and L2.
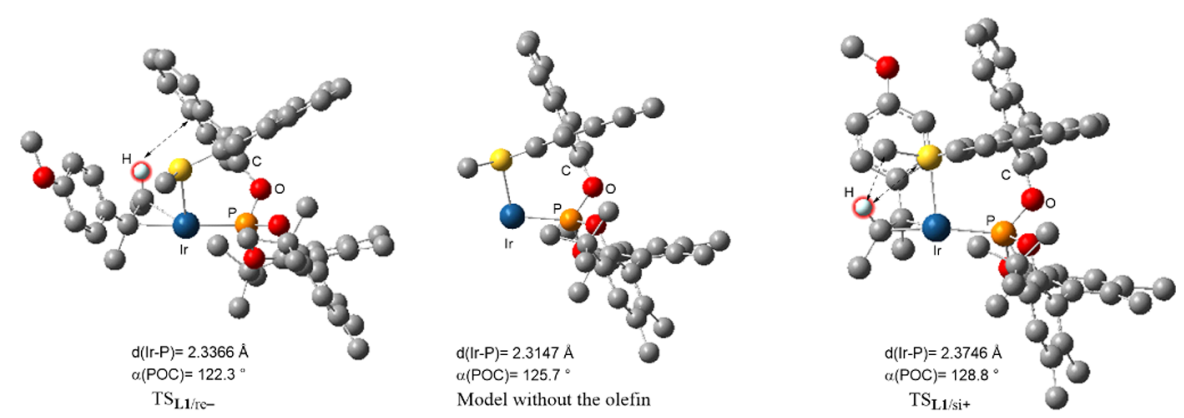

Figure 5. Comparison of calculated structures of $\mathrm{TS}_{\mathrm{L1} / r e^{-}}$and $\mathrm{TS}_{\mathrm{L} 1 / s i^{+}}$with the model structure without the olefin.
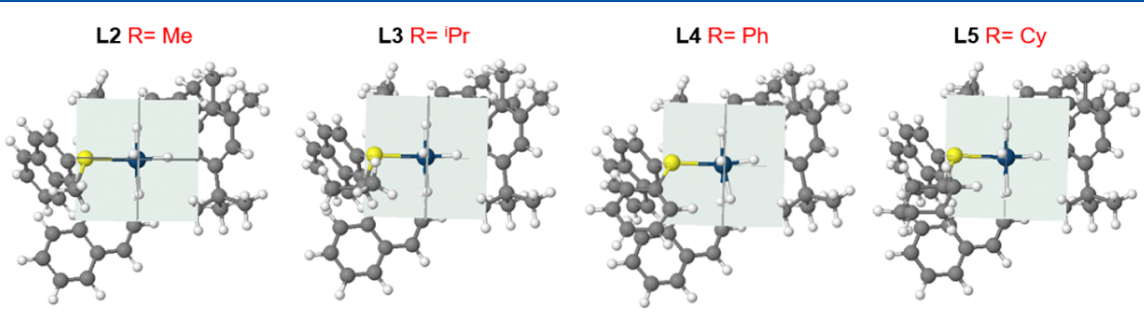

\begin{tabular}{|c|c|}
\hline 0 & 0.4 \\
\hline 2.5 & 0.6 \\
\hline
\end{tabular}

\begin{tabular}{|c|c|}
\hline 0 & 0.4 \\
\hline 5.5 & 0.6 \\
\hline
\end{tabular}

\begin{tabular}{|c|c|}
\hline 0 & 0.4 \\
\hline 7.7 & 0.6 \\
\hline
\end{tabular}

\begin{tabular}{|c|c|}
\hline 0 & 0.4 \\
\hline 8.8 & 0.6 \\
\hline
\end{tabular}

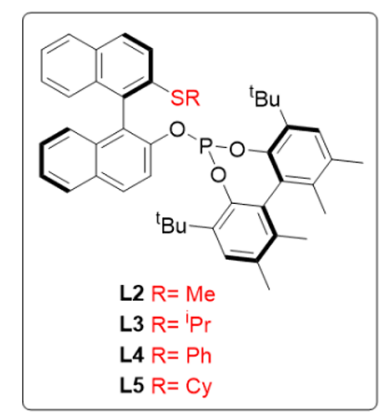

Figure 6. Models of the most stable TS of Ir-catalysts with ligands L2-L5. The partial occupation of each quadrant according to MolQuO is shown.

The results with ligands L6-L9 indicated that the presence of an achiral biphenyl phosphite moiety decreases enantioselectivities (e.g., entries $1-3$ vs 4,5 , and 7 , respectively). Therefore, the chiral binaphthyl ligand backbone together with the thioether group is not able to efficiently prevent the tropoisomerization of the biphenyl phosphite moiety in ligands L6-L9.

It is to note the very low enantioselectivity of ligand $\mathbf{L 8}$ with a phenyl thioether group (entry 6). This was unexpected because with the analogous ligand L4 (Figure 6), containing a chiral biaryl phosphite group, the hindered quadrant is highly 
Table 2. Asymmetric Hydrogenation of S1 Using Ligands $\mathrm{L} 3$ and L5-L9 ${ }^{a}$

\begin{tabular}{|c|c|c|c|}
\hline Entry & Ligand & $\%$ Conv (\% yield) & $\% \mathrm{ee}^{\mathrm{c}}$ \\
\hline 1 & L2 & 100 & $63(S)$ \\
\hline 2 & L3 & $100(94)$ & $80(S)$ \\
\hline 3 & L5 & 100 & $83(S)$ \\
\hline 4 & L6 & 100 & $40(S)$ \\
\hline 5 & L7 & $100(95)$ & $74(S)$ \\
\hline 6 & L8 & 100 & $1(S)$ \\
\hline 7 & L9 & 100 & $66(S)$ \\
\hline & & . & $\begin{array}{l}-{ }^{-} \mathrm{Bu} \\
\mathrm{R}=\mathrm{Me} \\
\mathrm{R}=\mathrm{Pr} \\
\mathrm{R}=\mathrm{Ph} \\
\mathrm{R}=\mathrm{Cy}\end{array}$ \\
\hline
\end{tabular}

${ }^{a}$ Reaction conditions: $0.25 \mathrm{~mol} \mathrm{S1}, 1 \mathrm{~mol} \%[\operatorname{Ir}(\operatorname{cod}) \mathbf{L}] \mathrm{BAr}_{\mathrm{F}}, \mathrm{P}_{\mathrm{H} 2}=$ 100 bar, rt., 18 h. ${ }^{b}$ Conversion measured by ${ }^{1} \mathrm{H}$ NMR. Isolated yield in parenthesis. ${ }^{c}$ Enantiomeric excess determined by GC.

occupied (Figure 6). This can be explained by the ability of the phenyl thioether substituent to establish a $\pi$-stacking interaction with the olefinic aryl ring that we observed in DFT calculations of the TSs with the analogous catalyst with ligand L4. It was seen that there is almost no energy difference $\left(\Delta(\Delta G)^{\#}=0.34 \mathrm{kcal} / \mathrm{mol}\right)$ between the two most stable TSs containing, at the most hindered quadrant, the olefinic hydrogen $\left(\mathrm{TS}_{\mathrm{L} 4 / \text { ret }}\right)$ or the olefinic aryl substituent $\left(\mathrm{TS}_{\mathrm{L} 4 / s i-}\right.$; see the Supporting Information).

Asymmetric Hydrogenation of Other Substrates: Scope and Limitations. We next studied whether our computationally based catalyst design can be extended to other olefins with the same geometry and substitution pattern as S1 (Figure 7). ${ }^{10}$ The Ir/L5 catalyst was used as it provided the

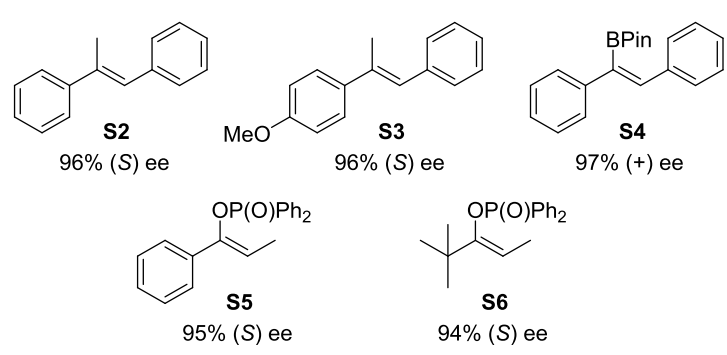

Figure 7. Asymmetric hydrogenation of trisubstituted olefins S2-S6. Reaction conditions: $1 \mathrm{~mol} \%[\operatorname{Ir}(\operatorname{cod}) \mathbf{L 5}] \mathrm{BAr}_{\mathrm{F}}, \mathrm{CH}_{2} \mathrm{Cl}_{2}$ as a solvent, 100 bar $\mathrm{H}_{2}$, rt., $18 \mathrm{~h}$. Full conversions were attained in all cases.

best results. Interestingly, the design proved to work even better than that for $\mathbf{S 1}$ when replacing the methyl groups by either a phenyl (olefin S2 and S3) or polar groups with different coordinating abilities (from olefin S4 with a coordinative group that is expected not to form a stable chelate ring with iridium to S5 and S6 with coordinative groups that can bind to the metal). For all of them, high enantioselectivities (up to $97 \%$ ee) comparable to the best one reported were attained, demonstrating the usefulness of this computational approach for designing a catalyst. The effective reduction of enol phosphinates and alkenylboronic esters is of particular importance because they can further be transformed into high-value products such alcohols (an alternative pathway to the reduction of ketones) and chiral boron compounds (whose $\mathrm{C}-\mathrm{B}$ bond can be easily converted to chiral C-C, C$\mathrm{N}$, and $\mathrm{C}-\mathrm{O}$ bonds). ${ }^{11}$ Despite their importance, they have been less studied than other trisubstituted olefins with polar functional groups. In addition, one can highlight the effective reduction of the purely alkyl-substituted enol phosphinate S6, a good alternative to the reduction of dialkyl ketones to alcohols with $\mathrm{Rh} / \mathrm{Ru}$-systems whose hydrogenation remains elusive.

To further establish the application range of $\operatorname{Ir} / \mathbf{L} \mathbf{1}-\mathbf{L} 9$, we moved to the asymmetric hydrogenation of other relevant olefins with poorly coordinative groups such as $\alpha, \beta$ disubstituted unsaturated ketones, lactones, and lactams (Figure 8). ${ }^{12}$ Their reduction is of interest because it facilitates
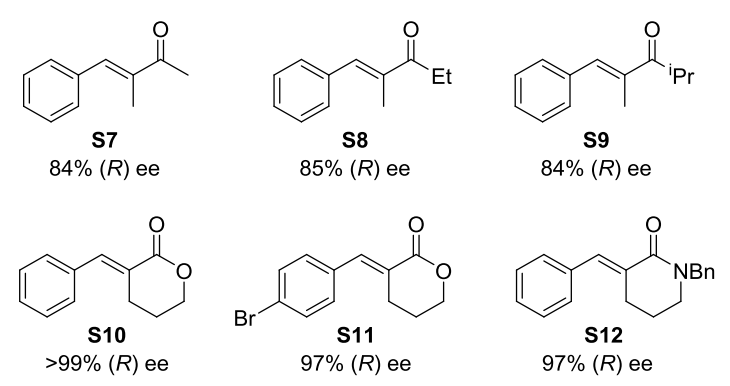

Figure 8. Asymmetric hydrogenation of $\alpha, \beta$-disubstituted unsaturated ketones, lactones, and lactams S7-S12. Reaction conditions: $1 \mathrm{~mol} \%$ $[\mathrm{Ir}(\operatorname{cod}) \mathbf{L 1}] \mathrm{BAr}_{\mathrm{F}}, \mathrm{CH}_{2} \mathrm{Cl}_{2}$ as a solvent, 100 bar $\mathrm{H}_{2}$, rt., 18 h. Full conversions were attained in all cases.

installing a tertiary chiral stereocenter at the $\alpha$-position of a carbonyl, lactone, and lactam group. Such motifs are present in many natural products, drugs, and commodity chemicals. ${ }^{2 \mathrm{~b}, 13}$ However, they do not resemble $\mathbf{S 1}$ or related substrates S2S6, neither in the olefin substitution pattern nor in the polarization of the alkene. As a result, it should be expected that the computed catalyst design would not completely fit such substrates, and we therefore screened all the catalyst precursors prepared (see the Supporting Information for the full set of results). We identified $\mathrm{Ir} / \mathbf{L} \mathbf{1}$, with an opposite configuration of the biaryl phosphite moiety rather than Ir/L5 and with a methyl thioether substituent, as a suitable catalytic system for their reductions (Figure 8). Ir/L1 provides excellent enantiocontrol in the hydrogenation of $\alpha, \beta$-disubstituted unsaturated lactones and lactams (S10-S12; ee values up to $>99$ and $97 \%$, respectively), comparable to the best reported so far.

Ir/L1-L9 catalyst precursors were also tested in the reduction of 1,1' -disubstituted alkenes (S13-S20; Figure 9). These are less hindered than the previously studied trisubstituted olefins, and face-selectivity is harder to control. In addition, they can isomerize to the most stable $E$ trisubstituted olefins, which are reduced to the opposite enantiomers. The effective reduction of these alkenes was only reached recently and with a limited number of catalysts. ${ }^{14} \mathrm{We}$ selected a set of $1,1^{\prime}$-disubstituted olefins with different functional groups that covers from no coordinative (S13- 


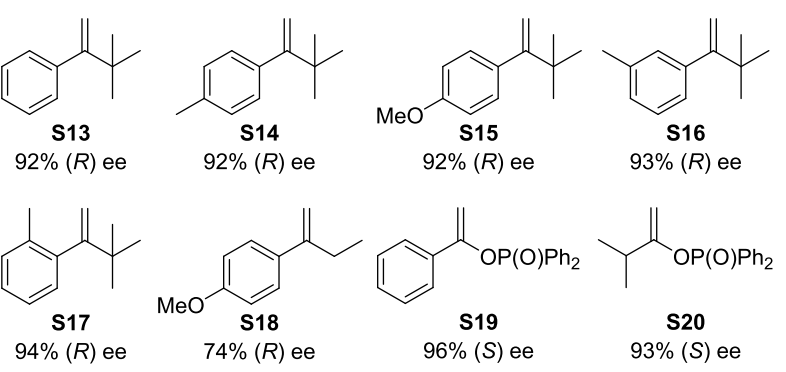

Figure 9. Asymmetric hydrogenation of $1,1^{\prime}$-disubstituted alkenes S13-S20. Reaction conditions: $1 \mathrm{~mol} \%[\operatorname{Ir}(\operatorname{cod}) \mathbf{L}] \mathrm{BAr}_{\mathrm{F}}(\mathbf{L}=\mathbf{L} \mathbf{2}$ for substrates S13-S18; $\mathbf{L}=\mathbf{L} 9$ for $\mathbf{S 1 9}$ and $\mathbf{S 2 0}), \mathrm{CH}_{2} \mathrm{Cl}_{2}$ as a solvent, 100 bar $\mathrm{H}_{2}$, rt., 18 h. Full conversions were attained in all cases.

S18) to coordinative (S19 and S20). Substrates S13-S17 could be effectively hydrogenated with Ir/L2 (ee values up to 94\%) independent of the steric and electronic character of the substituent in the aryl group. Like in most successful reports, the reduction of $\mathbf{S 1 8}$ with a less sterically alkyl substituents proceeded with lower enantioselectivities due to the isomerization side reaction. ${ }^{14,15}$ It is also to note that the high enantioselectivity reached in the reduction of trisubstituted enol phosphinates was also retained for the more challenging $1,1^{\prime}$-disubstituted analogue $\mathbf{S 1 9}$ and even in the reduction of the purely alkyl-substituted S20, but with the Ir/L9 system, which has an achiral biphenyl phosphite moiety.

Finally, we studied the asymmetric hydrogenation of cyclic $\beta$-enamides (Figure 10). Their hydrogenation opens up a

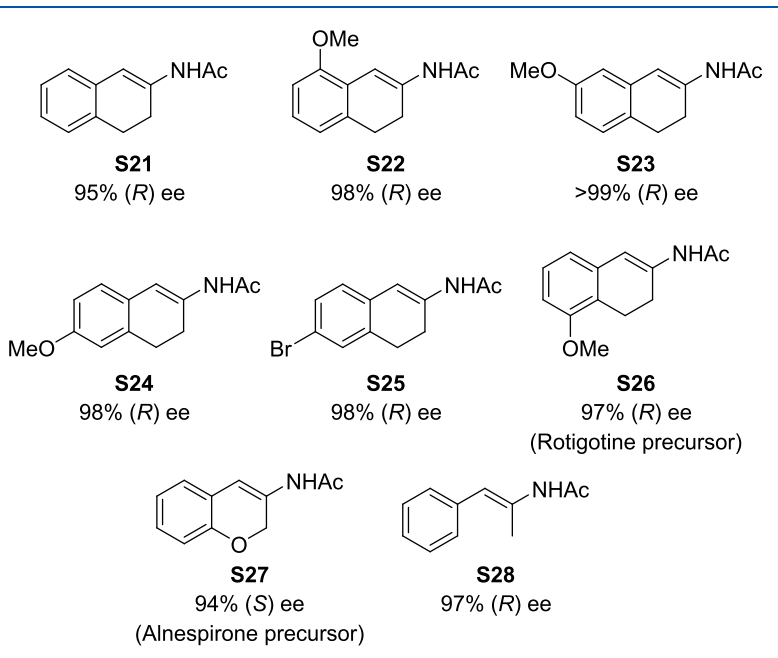

Figure 10. Asymmetric hydrogenation of $\beta$-enamides S21-S28. Reaction conditions: $1 \mathrm{~mol} \%[\operatorname{Ir}(\operatorname{cod}) \mathbf{L} 2] \mathrm{BAr}_{\mathrm{F}}, \mathrm{CH}_{2} \mathrm{Cl}_{2}$ as a solvent, 100 bar $\mathrm{H}_{2}$, rt., $12 \mathrm{~h}$. Full conversions were attained in all cases.

straightforward route to the synthesis of the 2-amino-1,2dihydronaphthalene core, which is present in many natural products and pharmaceuticals (e.g., rotigotine, alnespirone, and robalzotan). ${ }^{16}$ Although cyclic $\beta$-enamides have the same substitution pattern as olefins S7-S12, they contain a strong coordinating group, which has been the focus of most of the research in $\mathrm{Rh} / \mathrm{Ru}$-catalysts with a limited success and substrate scope. ${ }^{17}$ More recently, Riera's group made an important breakthrough by using Ir-P,N catalysts, commonly used for unfunctionalized olefins, that could reduce cyclic $\beta$ enamides derived from 2-tetralones with better results than those reported with $\mathrm{Ru} / \mathrm{Rh}$-catalysts. ${ }^{18}$ Subsequently, our group showed that Ir-P,thioether catalysts also have a comparably high catalytic performance. ${ }^{19}$ We initially studied the reduction of $\mathrm{N}$-(3,4-dihydronaphthalen-2-yl)acetamide S21 as the benchmark alkene under the optimal reaction conditions previously reported. ${ }^{19}$ The screening of Ir/L1-L9 catalytic systems allowed us to identify $\mathrm{Ir} / \mathbf{L} \mathbf{2}$ as an efficient catalytic system for the hydrogenation of S21 (see the Supporting Information). The excellent enantiocontrol was extended to a range of cyclic $\beta$-enamides derived from 2 tetralones, displaying all possible substitution patterns at the fused benzene ring and with several substituents (S21-S26; Figure 10). High ee values were also attained in the hydrogenation of a 3-chromanone derivative (substrate S27) as well as of the linear $\beta$-enamide S28. Among these successful reductions, note those with substrates S26 and S27, which are precursors for the drugs rotigotine and alnespirone, respectively.

\section{CONCLUSIONS}

We have shown the feasibility of in silico optimization of Ir/ P,S-catalysts for the asymmetric hydrogenation of $(E)$-1-(but2-en-2-yl)-4-methoxybenzene S1. The key to speed up the process has been the election of the highly rigid chiral $1,1^{\prime}$ binapththalene core, which reduces the number of conformations of the chelate ring. DFT calculations revealed that the bulkiness of the thioether has a major role in blocking, with more or less success, one of the quadrants. As a result, it is possible to direct the olefin coordination, thus overcoming very common face selectivity issues and controlling the relative position of the axial hydride and the hydrogen. Calculations also showed that the chirality of the biphenyl phosphite needs to be controlled to maximize the energy gap between the most stable TSs leading to opposite enantiomers. We therefore discovered the Ir-L5 catalytic system, which contains a cyclohexyl thioether group and an S-biphenyl phosphite group, as the most enantioselective for the hydrogenation of S1. Appealingly, the high enantiocontrol exerted by the Ir-L5 catalyst was maintained in the hydrogenation of other olefins containing the same substitution pattern and olefin geometry, regardless of the presence of other functional groups or their coordination abilities. Interestingly, further modifications on the thioether groups and the biaryl phosphite moiety allowed the highly enantioselective hydrogenation of olefins with different geometry patterns (such as $\alpha, \beta$-unsaturated lactones and lactams, 1,1'-disubstituted enol phosphinates, and cyclic $\beta$ enamides). To sum up, we here showed the usefulness of an in silico-based catalyst optimization for the discovery of an efficient Ir-P,S catalyst family, whose application in asymmetric catalysis had been discarded because early studies failed.

\section{EXPERIMENTAL SECTION}

General Considerations. All syntheses were performed by using standard Schlenk techniques under an argon atmosphere. Solvents were purified by standard procedures. Phosphorochloridites are easily prepared in one step from the corresponding biaryls. ${ }^{20}$ The synthesis of binol-based hydroxyl-thioether ligand precursors is discussed in the Supporting Information. All other reagents used were commercially available. ${ }^{1} \mathrm{H},{ }^{13} \mathrm{C}\left\{{ }^{1} \mathrm{H}\right\}$, and ${ }^{31} \mathrm{P}\left\{{ }^{1} \mathrm{H}\right\}$ NMR spectra experiments were recorded using a $400 \mathrm{MHz}$ spectrometer. Chemical shifts are relative to that of $\mathrm{SiMe}_{4}\left({ }^{1} \mathrm{H}\right.$ and $\left.{ }^{13} \mathrm{C}\right)$ as an internal standard or $\mathrm{H}_{3} \mathrm{PO}_{4}\left({ }^{31} \mathrm{P}\right)$ as an external standard. ${ }^{1} \mathrm{H}$ and ${ }^{13} \mathrm{C}$ assignments were done based on ${ }^{1} \mathrm{H}-{ }^{1} \mathrm{H}$ gCOSY and ${ }^{1} \mathrm{H}-{ }^{13} \mathrm{C}$ gHSQC experiments.

Computational Details. All minima and TSs were located using the Gaussian 09 program, ${ }^{21}$ employing the B $3 L Y P^{22}$ density 
functional along with Grimme's dispersion correction GD3. ${ }^{23}$ The 6$31 \mathrm{G}^{* 24}$ basis set was used for all atoms except for iridium, for which the LANL2DZ ${ }^{25}$ basis set was used together with the corresponding electron core potential. Solvent effects were taken into account along geometry optimizations using the polarized continuum model $\mathrm{PCM}^{26}$ with default parameters for dichloromethane. Frequency calculations have been carried out to check the nature of the located species and to obtain the free energies in solution. The energies were further refined by performing single point calculations with $\mathrm{PBEPBE}^{27}$ as the density functional along with Grimme's dispersion correction $\mathrm{GD} 2^{28}$ and the $6-311 \mathrm{G}^{* 29}$ basis set for all elements except iridium. This is owing to the high accuracy of this calculation method observed by Hopmann in the iridium mediated hydrogenation reactions. ${ }^{30}$ All energies reported are Gibbs free energies in solution with the Quasi-Harmonic approximation $^{31,32}$ at $298.15 \mathrm{~K}$ and in $\mathrm{kcal} \mathrm{mol}^{-1}$ (see the Supporting Information for further details).

General Procedure for the Preparation of PhosphiteThioether Ligands. Ligands L1-L9 were prepared following a methodology previously developed in our group. ${ }^{6 \mathrm{a}}$ The corresponding phosphorochloridite $(1.1 \mathrm{mmol})$ produced in situ was dissolved in toluene $(5 \mathrm{~mL})$, and triethylamine $(2.2 \mathrm{mmol}, 0.3 \mathrm{~mL})$ was added. The corresponding hydroxyl-thioether compound $(1 \mathrm{mmol})$ was azeotropically dried with toluene $(3 \times 1 \mathrm{~mL})$ and dissolved in toluene $(5 \mathrm{~mL})$ to which triethylamine $(2.2 \mathrm{mmol}, 0.3 \mathrm{~mL})$ was added. The solution was transferred slowly at $0{ }^{\circ} \mathrm{C}$ to the solution of the phosphorochloridite. The reaction mixture was stirred overnight at 80 ${ }^{\circ} \mathrm{C}$, and the triethylamine salts were removed by filtration. Evaporation of the solvent gave a white foam, which was purified by flash chromatography in silica (eluent: toluene/triethylamine, 100:1) to produce the corresponding ligand as a white solid.

L1: Yield: $115 \mathrm{mg}(33 \%) .{ }^{31} \mathrm{P}$ NMR $\left(161.9 \mathrm{MHz}, \mathrm{C}_{6} \mathrm{D}_{6}\right), \delta: 131.4$ (s). ${ }^{1} \mathrm{H}$ NMR (400 MHz, $\left.\mathrm{C}_{6} \mathrm{D}_{6}\right), \delta: 1.37\left(\mathrm{~s}, 9 \mathrm{H}, \mathrm{CH}_{3},{ }^{\mathrm{t}} \mathrm{Bu}\right), 1.43(\mathrm{~s}$, $\left.9 \mathrm{H}, \mathrm{CH}_{3},{ }^{\mathrm{t}} \mathrm{Bu}\right), 1.67\left(\mathrm{~s}, 3 \mathrm{H}, \mathrm{CH}_{3}\right), 1.74\left(\mathrm{~s}, 3 \mathrm{H}, \mathrm{CH}_{3}\right), 1.94(\mathrm{~s}, 3 \mathrm{H}$, $\left.\mathrm{SCH}_{3}\right), 2.02\left(\mathrm{~s}, 3 \mathrm{H}, \mathrm{CH}_{3}\right), 2.08\left(\mathrm{~s}, 3 \mathrm{H}, \mathrm{CH}_{3}\right), 6.96-7.06(\mathrm{~m}, 3 \mathrm{H}$, $\mathrm{CH}=), 7.07-7.12(\mathrm{~m}, 3 \mathrm{H}, \mathrm{CH}=), 7.16-7.18(\mathrm{~m}, 1 \mathrm{H}, \mathrm{CH}=), 7.27-$ $7.36(\mathrm{~m}, 2 \mathrm{H}, \mathrm{CH}=), 7.49-7.51(\mathrm{~m}, 1 \mathrm{H}, \mathrm{CH}=), 7.58-7.69(\mathrm{~m}, 4 \mathrm{H}$, $\mathrm{CH}=) .{ }^{13} \mathrm{C}$ NMR $\left(100.6 \mathrm{MHz}, \mathrm{C}_{6} \mathrm{D}_{6}\right), \delta: 15.5\left(\mathrm{SCH}_{3}\right), 16.4\left(\mathrm{CH}_{3}\right)$, $16.6\left(\mathrm{CH}_{3}\right), 20.2\left(\mathrm{CH}_{3}\right), 20.3\left(\mathrm{CH}_{3}\right), 31.3\left(\mathrm{~d}, \mathrm{CH}_{3},{ }^{\mathrm{t}} \mathrm{Bu}, J_{\mathrm{C}-\mathrm{P}}=5.1\right.$ $\mathrm{Hz}), 31.7\left(\mathrm{CH}_{3},{ }^{\mathrm{t}} \mathrm{Bu}\right), 34.7\left(\mathrm{C},{ }^{\mathrm{t}} \mathrm{Bu}\right), 34.7\left(\mathrm{C},{ }^{\mathrm{t}} \mathrm{Bu}\right), 122.2-148.0$ (aromatic carbons). Anal. Calcd (\%) for $\mathrm{C}_{45} \mathrm{H}_{47} \mathrm{O}_{3} \mathrm{PS}$ : C 77.33, $\mathrm{H}$ 6.78, S 4.59. Found: C 77.07, H 6.76, S 4.57. MS HR-ESI [found 721.2871, $\mathrm{C}_{45} \mathrm{H}_{47} \mathrm{O}_{3} \mathrm{PSNa}(\mathrm{M}+\mathrm{Na})^{+}$requires 721.2876$]$.

L2: Yield: $157 \mathrm{mg}(45 \%) .{ }^{31} \mathrm{P}$ NMR (161.9 MHz, $\left.\mathrm{C}_{6} \mathrm{D}_{6}\right), \delta: 132.1$ (s). ${ }^{1} \mathrm{H}$ NMR (400 MHz, $\left.\mathrm{C}_{6} \mathrm{D}_{6}\right), \delta: 1.22\left(\mathrm{~s}, 9 \mathrm{H}, \mathrm{CH}_{3},{ }^{\mathrm{t}} \mathrm{Bu}\right), 1.46(\mathrm{~s}$, $\left.9 \mathrm{H}, \mathrm{CH}_{3},{ }^{\mathrm{t}} \mathrm{Bu}\right), 1.69\left(\mathrm{~s}, 3 \mathrm{H}, \mathrm{CH}_{3}\right), 1.87\left(\mathrm{~s}, 3 \mathrm{H}, \mathrm{CH}_{3}\right), 1.96(\mathrm{~s}, 3 \mathrm{H}$, $\left.\mathrm{CH}_{3}\right), 2.06\left(\mathrm{~s}, 3 \mathrm{H}, \mathrm{SCH}_{3}\right), 2.19\left(\mathrm{~s}, 3 \mathrm{H}, \mathrm{CH}_{3}\right), 6.97-7.07(\mathrm{~m}, 4 \mathrm{H}$, $\mathrm{CH}=)$ 7.11-7.17 (m, 3H, CH=), 7.19-7.31 (m, 4H, CH=), 7.58$7.60(\mathrm{~m}, 2 \mathrm{H}, \mathrm{CH}=), 7.70-7.72(\mathrm{~m}, 1 \mathrm{H}, \mathrm{CH}=) .{ }^{13} \mathrm{C}$ NMR $(100.6$ $\left.\mathrm{MHz}, \mathrm{C}_{6} \mathrm{D}_{6}\right), \delta: 16.2\left(\mathrm{CH}_{3}\right), 16.3\left(\mathrm{CH}_{3}\right), 16.5\left(\mathrm{CH}_{3}\right), 16.6\left(\mathrm{CH}_{3}\right)$, $20.1\left(\mathrm{SCH}_{3}\right), 31.3\left(\mathrm{~d}, \mathrm{CH}_{3},{ }^{\mathrm{t}} \mathrm{Bu}, J_{\mathrm{C}-\mathrm{P}}=5.1 \mathrm{~Hz}\right), 31.5\left(\mathrm{CH}_{3},{ }^{\mathrm{t}} \mathrm{Bu}\right), 34.5$ $\left(\mathrm{C},{ }^{\mathrm{t}} \mathrm{Bu}\right), 34.7\left(\mathrm{C},{ }^{\mathrm{t}} \mathrm{Bu}\right), 122.7-147.4$ (aromatic carbons). Anal. Calcd (\%) for $\mathrm{C}_{45} \mathrm{H}_{47} \mathrm{O}_{3} \mathrm{PS}$ : C 77.33, $\mathrm{H}$ 6.78, S 4.59. Found: $\mathrm{C}$ 77.14, $\mathrm{H}$ 6.76, S 4.58. MS HR-ESI [found 721.2871, $\mathrm{C}_{45} \mathrm{H}_{47} \mathrm{O}_{3} \mathrm{PSNa}(\mathrm{M}+$ $\mathrm{Na})^{+}$requires 721.2876$]$.

L3: Yield: $150 \mathrm{mg}(41 \%) .{ }^{31} \mathrm{P}$ NMR (161.9 MHz, $\left.\mathrm{C}_{6} \mathrm{D}_{6}\right), \delta: 131.7$ (s). ${ }^{1} \mathrm{H}$ NMR $\left(400 \mathrm{MHz}, \mathrm{C}_{6} \mathrm{D}_{6}\right), \delta: 0.93\left(\mathrm{~d}, 3 \mathrm{H}, \mathrm{CH}_{3}, \mathrm{~S}^{\mathrm{i} P r},{ }^{3} J_{\mathrm{H}-\mathrm{H}}=\right.$ $6.6 \mathrm{~Hz}), 1.03\left(\mathrm{~d}, 3 \mathrm{H}, \mathrm{CH}_{3}, \mathrm{~S}^{\mathrm{i}} \operatorname{Pr},{ }^{3} \mathrm{~J}_{\mathrm{H}-\mathrm{H}}=6.6 \mathrm{~Hz}\right), 1.25\left(\mathrm{~s}, 9 \mathrm{H}, \mathrm{CH}_{3}\right.$, $\left.{ }^{\mathrm{t}} \mathrm{Bu}\right), 1.47\left(\mathrm{~s}, 9 \mathrm{H}, \mathrm{CH}_{3},{ }^{\mathrm{t}} \mathrm{Bu}\right), 1.67\left(\mathrm{~s}, 3 \mathrm{H}, \mathrm{CH}_{3}\right), 1.71\left(\mathrm{~s}, 3 \mathrm{H}, \mathrm{CH}_{3}\right)$, $2.03\left(\mathrm{~s}, 3 \mathrm{H}, \mathrm{CH}_{3}\right), 2.05\left(\mathrm{~s}, 3 \mathrm{H}, \mathrm{CH}_{3}\right), 3.20(\mathrm{~m}, 1 \mathrm{H}, \mathrm{CH}, \mathrm{S}$ Pr), $6.93-$ $6.98(\mathrm{~m} 2 \mathrm{H}, \mathrm{CH}=), 7.00-7.14(\mathrm{~m}, 4 \mathrm{H}, \mathrm{CH}=), 7.18-7.24(\mathrm{~m}, 3 \mathrm{H}$, $\mathrm{CH}=)$, 7.44-7.46 (m, 1H, CH=), 7.55-7.60 (d, $1 \mathrm{H}, \mathrm{CH}=,{ }^{3} J_{\mathrm{H}-\mathrm{H}}=$ $8.8 \mathrm{~Hz}), 7.65-7.70(\mathrm{~m}, 3 \mathrm{H}, \mathrm{CH}=) .{ }^{13} \mathrm{C} \mathrm{NMR}\left(100.6 \mathrm{MHz}, \mathrm{C}_{6} \mathrm{D}_{6}\right), \delta$ : $16.3\left(\mathrm{CH}_{3}\right), 16.5\left(\mathrm{CH}_{3}\right), 20.0\left(\mathrm{CH}_{3}\right), 20.1\left(\mathrm{CH}_{3}\right), 22.3\left(\mathrm{CH}_{3}, \mathrm{~S} \mathrm{Pr}\right)$, $22.9\left(\mathrm{CH}_{3}, \mathrm{~S} \mathrm{Pr}\right), 31.3\left(\mathrm{CH}_{3},{ }^{\mathrm{t}} \mathrm{Bu}\right), 31.3\left(\mathrm{CH}_{3},{ }^{\mathrm{t}} \mathrm{Bu}\right), 34.5\left(2 \mathrm{x} \mathrm{C},{ }^{\mathrm{t}} \mathrm{Bu}\right)$, $36.0\left(\mathrm{CH}, \mathrm{S}^{\mathrm{i}} \mathrm{Pr}\right), 122.6-147.9$ (aromatic carbons). Anal. Calcd (\%) for $\mathrm{C}_{47} \mathrm{H}_{51} \mathrm{O}_{3}$ PS: $\mathrm{C} 77.65, \mathrm{H}$ 7.07, S 4.41. Found: $\mathrm{C} 77.5314, \mathrm{H}$ 7.05, $S$ 4.39. MS HR-ESI [found 749.3186, $\mathrm{C}_{47} \mathrm{H}_{51} \mathrm{O}_{3} \mathrm{PSNa}(\mathrm{M}+\mathrm{Na})^{+}$ requires 749.3189$]$.

L5: Yield: $179 \mathrm{mg}(47 \%) .{ }^{31} \mathrm{P}$ NMR (161.9 MHz, $\left.\mathrm{C}_{6} \mathrm{D}_{6}\right), \delta: 131.7$ (s). ${ }^{1} \mathrm{H}$ NMR (400 MHz, $\left.\mathrm{C}_{6} \mathrm{D}_{6}\right), \delta: 0.85-1.04\left(\mathrm{~m}, 5 \mathrm{H}, \mathrm{CH}_{2}, \mathrm{SCy}\right)$, $1.12-1.16\left(\mathrm{~m}, 1 \mathrm{H}, \mathrm{CH}_{2}, \mathrm{SCy}\right), 1.22\left(\mathrm{~s}, 9 \mathrm{H}, \mathrm{CH}_{3},{ }^{\mathrm{t}} \mathrm{Bu}\right), 1.24-1.28(\mathrm{~m}$, $\left.1 \mathrm{H}, \mathrm{CH}_{2}, \mathrm{SCy}\right), 1.34-1.39$ (m, $\left.2 \mathrm{H}, \mathrm{CH}_{2}, \mathrm{SCy}\right), 1.42\left(\mathrm{~s}, 9 \mathrm{H}, \mathrm{CH}_{3}\right.$, $\left.{ }^{\mathrm{t}} \mathrm{Bu}\right), 1.62\left(\mathrm{~s}, 3 \mathrm{H}, \mathrm{CH}_{3}\right), 1.66\left(\mathrm{~s}, 3 \mathrm{H}, \mathrm{CH}_{3}\right), 1.86-1.90\left(\mathrm{~m}, 1 \mathrm{H}, \mathrm{CH}_{2}\right.$, $\mathrm{SCy}), 1.98\left(\mathrm{~s}, 3 \mathrm{H}, \mathrm{CH}_{3}\right), 2.00\left(\mathrm{~s}, 3 \mathrm{H}, \mathrm{CH}_{3}\right), 2.97-3.02(\mathrm{~m}, 1 \mathrm{H}, \mathrm{CH}$, $\mathrm{SCy}), 6.89-6.93(\mathrm{~m}, 2 \mathrm{H}, \mathrm{CH}=), 6.95-6.97(\mathrm{~m}, 2 \mathrm{H}, \mathrm{CH}=), 7.06-$ $7.08(\mathrm{~m}, 2 \mathrm{H}, \mathrm{CH}=), 7.14-7.15(\mathrm{~m}, 2 \mathrm{H}, \mathrm{CH}=), 7.49-7.56(\mathrm{~m}, 3 \mathrm{H}$, $\mathrm{CH}=), 7.61-7.65(\mathrm{~m}, 3 \mathrm{H}, \mathrm{CH}=) .{ }^{13} \mathrm{C}$ NMR $\left(100.6 \mathrm{MHz}, \mathrm{C}_{6} \mathrm{D}_{6}\right), \delta$ : $16.3\left(\mathrm{CH}_{3}\right), 16.5\left(\mathrm{CH}_{3}\right), 20.0\left(\mathrm{CH}_{3}\right), 20.2\left(\mathrm{CH}_{3}\right), 25.6\left(\mathrm{CH}_{2}, \mathrm{SCy}\right)$, $25.8\left(\mathrm{CH}_{2}, \mathrm{SCy}\right), 25.9\left(\mathrm{CH}_{2}, \mathrm{SCy}\right), 31.4\left(\mathrm{CH}_{3},{ }^{\mathrm{t}} \mathrm{Bu}\right), 31.4\left(\mathrm{CH}_{3}\right.$, $\left.{ }^{\mathrm{t}} \mathrm{Bu}\right), 32.9\left(\mathrm{CH}_{2}, \mathrm{SCy}\right), 33.2\left(\mathrm{CH}_{2}, \mathrm{SCy}\right), 34.6\left(\mathrm{C},{ }^{\mathrm{t}} \mathrm{Bu}\right), 34.6\left(\mathrm{C},{ }^{\mathrm{t}} \mathrm{Bu}\right)$, 44.8 (CH, SCy), 122.4-147.9 (aromatic carbons). Anal. Calcd (\%) for $\mathrm{C}_{50} \mathrm{H}_{55} \mathrm{O}_{3}$ PS: C 78.30, H 7.23, S 4.18. Found: C 78.16, H 7.21, S 4.15. MS HR-ESI [found 789.3500, $\mathrm{C}_{50} \mathrm{H}_{55} \mathrm{O}_{3} \mathrm{PSNa}(\mathrm{M}+\mathrm{Na})^{+}$ requires 789.3502$]$.

L6: Yield: $129.1 \mathrm{mg}(34 \%) .{ }^{31} \mathrm{P} \mathrm{NMR}\left(161.9 \mathrm{MHz}, \mathrm{C}_{6} \mathrm{D}_{6}\right), \delta: 136.5$ (s). ${ }^{1} \mathrm{H}$ NMR $\left(400 \mathrm{MHz}, \mathrm{C}_{6} \mathrm{D}_{6}\right), \delta: 1.26\left(\mathrm{~s}, 9 \mathrm{H}, \mathrm{CH}_{3},{ }^{\mathrm{t}} \mathrm{Bu}\right), 1.28(\mathrm{~s}$, $\left.18 \mathrm{H}, \mathrm{CH}_{3},{ }^{\mathrm{t}} \mathrm{Bu}\right), 1.44\left(\mathrm{~s}, 9 \mathrm{H}, \mathrm{CH}_{3},{ }^{\mathrm{t}} \mathrm{Bu}\right), 1.93\left(\mathrm{~s}, 3 \mathrm{H}, \mathrm{SCH}_{3}\right), 6.95-$ $7.05(\mathrm{~m}, 3 \mathrm{H}, \mathrm{CH}=), 7.08-7.14(\mathrm{~m}, 2 \mathrm{H}, \mathrm{CH}=), 7.17-7.21(\mathrm{~m}, 1 \mathrm{H}$, $\mathrm{CH}=)$, 7.28-7.36 (m, 4H, $\mathrm{CH}=), 7.51-7.63(\mathrm{~m}, 4 \mathrm{H}, \mathrm{CH}=), 7.70-$ $7.75(\mathrm{~m}, 2 \mathrm{H}, \mathrm{CH}=) .{ }^{13} \mathrm{C}$ NMR $\left(100.6 \mathrm{MHz}, \mathrm{C}_{6} \mathrm{D}_{6}\right), \delta: 15.3\left(\mathrm{SCH}_{3}\right)$, $31.0\left(\mathrm{~d}, \mathrm{CH}_{3},{ }^{\mathrm{t}} \mathrm{Bu}, J_{\mathrm{C}-\mathrm{P}}=1.8 \mathrm{~Hz}\right), 31.1\left(\mathrm{~d}, \mathrm{CH}_{3},{ }^{\mathrm{t}} \mathrm{Bu}, J_{\mathrm{C}-\mathrm{P}}=3.0 \mathrm{~Hz}\right)$, $31.4\left(\mathrm{~d}, \mathrm{CH}_{3}, 2{ }^{\mathrm{t}} \mathrm{Bu}, J_{\mathrm{C}-\mathrm{p}}=3.0 \mathrm{~Hz}\right), 34.3\left(\mathrm{C},{ }^{\mathrm{t}} \mathrm{Bu}\right), 34.4\left(\mathrm{C},{ }^{\mathrm{t}} \mathrm{Bu}\right), 35.3$ $\left(\mathrm{C},{ }^{\mathrm{t}} \mathrm{Bu}\right), 35.4\left(\mathrm{C},{ }^{\mathrm{t}} \mathrm{Bu}\right), 122.9-147.9$ (aromatic carbons). Anal. Calcd (\%) for $\mathrm{C}_{49} \mathrm{H}_{55} \mathrm{O}_{3}$ PS: $\mathrm{C} 77.95, \mathrm{H}$ 7.34, S 4.25. Found: $\mathrm{C} 77.87, \mathrm{H}$ 7.32, S 4.24. MS HR-ESI [found 777.3528, $\mathrm{C}_{49} \mathrm{H}_{55} \mathrm{O}_{3} \mathrm{PSNa}(\mathrm{M}+$ $\mathrm{Na})^{+}$requires 777.3502$]$.

L7: Yield: $251 \mathrm{mg}(64 \%) .{ }^{31} \mathrm{P}$ NMR $\left(161.9 \mathrm{MHz}, \mathrm{C}_{6} \mathrm{D}_{6}\right), \delta: 131.7$ (s). ${ }^{1} \mathrm{H}$ NMR $\left(400 \mathrm{MHz}, \mathrm{C}_{6} \mathrm{D}_{6}\right), \delta: 0.94\left(\mathrm{~d}, 3 \mathrm{H}, \mathrm{CH}_{3}, \mathrm{~S}^{\mathrm{i}} \mathrm{Pr},{ }^{3} J_{\mathrm{H}-\mathrm{H}}=\right.$ $6.6 \mathrm{~Hz}), 1.00\left(\mathrm{~d}, 3 \mathrm{H}, \mathrm{CH}_{3}, \mathrm{~S} \mathrm{Pr},{ }^{3} J_{\mathrm{H}-\mathrm{H}}=6.6 \mathrm{~Hz}\right), 1.25\left(\mathrm{~s}, 9 \mathrm{H}, \mathrm{CH}_{3}\right.$ $\left.{ }^{\mathrm{t}} \mathrm{Bu}\right), 1.27\left(\mathrm{~s}, 9 \mathrm{H}, \mathrm{CH}_{3},{ }^{\mathrm{t}} \mathrm{Bu}\right), 1.31\left(\mathrm{~s}, 9 \mathrm{H}, \mathrm{CH}_{3},{ }^{\mathrm{t}} \mathrm{Bu}\right), 1.46(\mathrm{~s}, 9 \mathrm{H}$, $\left.\mathrm{CH}_{3},{ }^{\mathrm{t}} \mathrm{Bu}\right), 3.18-3.25\left(\mathrm{~m}, 1 \mathrm{H}, \mathrm{CH}, \mathrm{S}^{\mathrm{i}} \mathrm{Pr}\right), 6.95-7.03(\mathrm{~m}, 2 \mathrm{H}, \mathrm{CH}=)$, 7.08-7.14 (m, $1 \mathrm{H}, \mathrm{CH}=), 7.18-7.22(\mathrm{~m}, 1 \mathrm{H}, \mathrm{CH}=), 7.25-7.30(\mathrm{~m}$, $2 \mathrm{H}, \mathrm{CH}=), 7.34-7.36(\mathrm{~m}, 2 \mathrm{H}, \mathrm{CH}=), 7.52-7.62(\mathrm{~m}, 6 \mathrm{H}, \mathrm{CH}=)$, 7.69-7.72 (m, 2H, $\mathrm{CH}=) .{ }^{13} \mathrm{C}$ NMR $\left(100.6 \mathrm{MHz}, \mathrm{C}_{6} \mathrm{D}_{6}\right), \delta: 22.4$ $\left(\mathrm{CH}_{3}, \mathrm{~S} \mathrm{Pr}\right), 23.0\left(\mathrm{CH}_{3}, \mathrm{~S}^{\mathrm{i}} \mathrm{Pr}\right), 31.0\left(\mathrm{~d}, \mathrm{CH}_{3},{ }^{\mathrm{t}} \mathrm{Bu}, J_{\mathrm{C}-\mathrm{P}}=1.9 \mathrm{~Hz}\right), 31.2$ $\left(\mathrm{d}, \mathrm{CH}_{3},{ }^{\mathrm{t}} \mathrm{Bu}, J_{\mathrm{C}-\mathrm{P}}=3.0 \mathrm{~Hz}\right), 31.2\left(\mathrm{~d}, \mathrm{CH}_{3}, 2 \mathrm{x}{ }^{\mathrm{t}} \mathrm{Bu}, J_{\mathrm{C}-\mathrm{P}}=2.2 \mathrm{~Hz} \mathrm{CH}_{3}\right.$, $\left.{ }^{\mathrm{t}} \mathrm{Bu}\right), 34.3\left(\mathrm{C},{ }^{\mathrm{t}} \mathrm{Bu}\right), 34.4\left(\mathrm{C},{ }^{\mathrm{t}} \mathrm{Bu}\right), 35.2\left(\mathrm{C},{ }^{\mathrm{t}} \mathrm{Bu}\right), 35.3\left(\mathrm{C},{ }^{\mathrm{t}} \mathrm{Bu}\right), 36.0$ (CH, SiPr), 122.6-147.7 (aromatic carbons). Anal. Calcd (\%) for $\mathrm{C}_{51} \mathrm{H}_{59} \mathrm{O}_{3}$ PS: C 78.23, H 7.59, S 4.09. Found: C 78.01, H 7.55, S 4.06. MS HR-ESI [found 805.3813, $\mathrm{C}_{51} \mathrm{H}_{59} \mathrm{O}_{3} \mathrm{PSNa}(\mathrm{M}+\mathrm{Na})^{+}$requires 805.3815].

L8: Yield: $55 \mathrm{mg}(11 \%) .{ }^{31} \mathrm{P}$ NMR (161.9 MHz, $\left.\mathrm{C}_{6} \mathrm{D}_{6}\right), \delta: 135.4$ (s). ${ }^{1} \mathrm{H}$ NMR $\left(400 \mathrm{MHz}, \mathrm{C}_{6} \mathrm{D}_{6}\right), \delta: 1.23\left(\mathrm{~s}, 18 \mathrm{H}, \mathrm{CH}_{3},{ }^{\mathrm{t}} \mathrm{Bu}\right), 1.25(\mathrm{~s}$, $\left.9 \mathrm{H}, \mathrm{CH}_{3},{ }^{\mathrm{t}} \mathrm{Bu}\right), 1.31\left(\mathrm{~s}, 9 \mathrm{H}, \mathrm{CH}_{3},{ }^{\mathrm{t}} \mathrm{Bu}\right), 6.79-6.82(\mathrm{~m}, 2 \mathrm{H}, \mathrm{CH}=)$, 6.92-6.99 (m, 2H, CH=), 7.04-7.12 (m, 2H, CH=), 7.14-7.17 (m, $1 \mathrm{H}, \mathrm{CH}=), 7.28-7.36(\mathrm{~m}, 6 \mathrm{H}, \mathrm{CH}=), 7.40-7.42\left(\mathrm{~m}, 1 \mathrm{H}, \mathrm{CH}=,{ }^{3} \mathrm{~J}_{\mathrm{H}-\mathrm{H}}\right.$ $=8.7 \mathrm{~Hz}), 7.48-7.59(\mathrm{~m}, 7 \mathrm{H}, \mathrm{CH}=) .{ }^{13} \mathrm{C} \mathrm{NMR}\left(100.6 \mathrm{MHz}, \mathrm{C}_{6} \mathrm{D}_{6}\right)$, $\delta: 30.9\left(2 \mathrm{x} \mathrm{CH}_{3},{ }^{\mathrm{t}} \mathrm{Bu}\right), 31.2\left(2 \mathrm{x} \mathrm{CH}_{3},{ }^{\mathrm{t}} \mathrm{Bu}\right), 34.3\left(\mathrm{C},{ }^{\mathrm{t}} \mathrm{Bu}\right), 34.3(\mathrm{C}$, $\left.{ }^{\mathrm{t}} \mathrm{Bu}\right), 35.2\left(2 \mathrm{x} \mathrm{C},{ }^{\mathrm{t}} \mathrm{Bu}\right), 122.5-146.8$ (aromatic carbons). Anal. Calcd (\%) for $\mathrm{C}_{54} \mathrm{H}_{57} \mathrm{O}_{3}$ PS: C 79.38, H 7.03, S 3.92. Found: C 79.15, H 6.99, S 3.90. MS HR-ESI [found 839.3655, $\mathrm{C}_{54} \mathrm{H}_{57} \mathrm{O}_{3} \mathrm{PSNa}(\mathrm{M}+$ $\mathrm{Na})^{+}$requires 839.3658$]$.

L9: Yield: $213 \mathrm{mg}(52 \%) .{ }^{31} \mathrm{P}$ NMR $\left(161.9 \mathrm{MHz}, \mathrm{C}_{6} \mathrm{D}_{6}\right), \delta: 135.6$ (s). ${ }^{1} \mathrm{H}$ NMR (400 MHz, $\left.\mathrm{C}_{6} \mathrm{D}_{6}\right), \delta: 0.84-1.07\left(\mathrm{~m}, 5 \mathrm{H}, \mathrm{CH}_{2}, \mathrm{SCy}\right)$, $1.26\left(\mathrm{~s}, 9 \mathrm{H}, \mathrm{CH}_{3},{ }^{\mathrm{t}} \mathrm{Bu}\right), 1.27\left(\mathrm{~s}, 9 \mathrm{H}, \mathrm{CH}_{3},{ }^{\mathrm{t}} \mathrm{Bu}\right), 1.32\left(\mathrm{~s}, 9 \mathrm{H}, \mathrm{CH}_{3}\right.$, $\left.{ }^{t} \mathrm{Bu}\right), 1.37-1.43\left(\mathrm{~m}, 3 \mathrm{H}, \mathrm{CH}_{2}, \mathrm{SCy}\right), 1.47\left(\mathrm{~s}, 9 \mathrm{H}, \mathrm{CH}_{3},{ }^{\mathrm{t}} \mathrm{Bu}\right), 1.69-$ 1.72 (b, $\left.1 \mathrm{H}, \mathrm{CH}_{2}, \mathrm{SCy}\right), 1.87-1.90\left(\mathrm{~b}, 1 \mathrm{H}, \mathrm{CH}_{2}, \mathrm{SCy}\right), 3.02-3.07$ (m, 1H, CH, SCy), 6.95-7.05 (m, 4H, CH=), 7.09-7.14 (m, 2H, $\mathrm{CH}=)$, 7.19-7.22 (m, 1H, $\mathrm{CH}=)$, 7.24-7.29 (m, 1H, CH=), 7.34$7.36(\mathrm{~m}, 2 \mathrm{H}, \mathrm{CH}=), 7.53-7.54(\mathrm{~m}, 1 \mathrm{H}, \mathrm{CH}=), 7.57-7.63(\mathrm{~m}, 4 \mathrm{H}$, $\mathrm{CH}=), 7.68-7.71(\mathrm{~m}, 1 \mathrm{H}, \mathrm{CH}=) .{ }^{13} \mathrm{C} \operatorname{NMR}\left(100.6 \mathrm{MHz}, \mathrm{C}_{6} \mathrm{D}_{6}\right), \delta$ : $25.6\left(\mathrm{CH}_{2}, \mathrm{SCy}\right), 25.8\left(\mathrm{CH}_{2}, \mathrm{SCy}\right), 25.9\left(\mathrm{CH}_{2}, \mathrm{SCy}\right), 31.0\left(\mathrm{~d}, \mathrm{CH}_{3}\right.$, $\left.{ }^{\mathrm{t}} \mathrm{Bu}, J_{\mathrm{C}-\mathrm{P}}=1.6 \mathrm{~Hz}\right), 31.2\left(\mathrm{CH}_{3},{ }^{\mathrm{t}} \mathrm{Bu}\right), 31.3\left(\mathrm{~d}, \mathrm{CH}_{3}, 2 \mathrm{x}{ }^{\mathrm{t}} \mathrm{Bu}, J_{\mathrm{C}-\mathrm{P}}=1.6\right.$ $\mathrm{Hz}), 32.8\left(\mathrm{CH}_{2}, \mathrm{SCy}\right), 33.3\left(\mathrm{CH}_{2}, \mathrm{SCy}\right), 34.3\left(\mathrm{C},{ }^{\mathrm{t}} \mathrm{Bu}\right), 34.4\left(\mathrm{C},{ }^{\mathrm{t}} \mathrm{Bu}\right)$, $35.2\left(\mathrm{C},{ }^{\mathrm{t}} \mathrm{Bu}\right), 35.3\left(\mathrm{C},{ }^{\mathrm{t}} \mathrm{Bu}\right), 44.8(\mathrm{CH}, \mathrm{SCy}), 122.6-147.7$ (aromatic carbons). Anal. Calcd (\%) for $\mathrm{C}_{54} \mathrm{H}_{63} \mathrm{O}_{3}$ PS: C 78.80, H 7.71, S 3.89. Found: C 78.62, H 7.69, S 3.87. MS HR-ESI [found 845.4124, $\mathrm{C}_{54} \mathrm{H}_{63} \mathrm{O}_{3} \mathrm{PSNa}(\mathrm{M}+\mathrm{Na})^{+}$requires 845.4128]. 
General Procedure for the Preparation of Iridium Catalyst Precursors $\left[\operatorname{Ir}(\mathrm{cod})(\mathrm{L} 1-\mathrm{L} 9) \mathrm{BAr}_{\mathrm{F}}\right]$. The Ir catalyst precursors were prepared following a methodology previously developed in our group. ${ }^{33}$ The corresponding ligand $(0.037 \mathrm{mmol})$ was dissolved in $\mathrm{CH}_{2} \mathrm{Cl}_{2}(2.5 \mathrm{~mL})$, and $[\mathrm{Ir}(\mu-\mathrm{Cl})(\operatorname{cod})]_{2}(12.5 \mathrm{mg}, 0.0185 \mathrm{mmol})$ was added. The reaction was refluxed at $50{ }^{\circ} \mathrm{C}$ for $1 \mathrm{~h}$. After $5 \mathrm{~min}$ at room temperature, $\mathrm{NaBAr}_{\mathrm{F}}(38.6 \mathrm{mg}, 0.041 \mathrm{mmol})$ and water $(2.5$ $\mathrm{mL}$ ) were added and the reaction was stirred vigorously for $30 \mathrm{~min}$ at room temperature. The phases were separated, and the aqueous one was extracted twice with $\mathrm{CH}_{2} \mathrm{Cl}_{2}$. The combined organic phases were dried with $\mathrm{MgSO}_{4}$, and the resulting crude was purified by flash chromatography on silica $\left(\mathrm{CH}_{2} \mathrm{Cl}_{2} /\right.$ hexane, $\left.1: 1\right)$ to give orange-red air-stable solids.

$[\operatorname{Ir}(\operatorname{cod})(\mathrm{L} 1)] \mathrm{BAr}_{\mathrm{F}}$. Yield: $65 \mathrm{mg}(93 \%) .{ }^{31} \mathrm{P}$ NMR $(161.9 \mathrm{MHz}$, $\left.\mathrm{CDCl}_{3}\right), \delta: 108.5$ (s). ${ }^{1} \mathrm{H}$ NMR $\left(400 \mathrm{MHz}, \mathrm{CDCl}_{3}\right), \delta: 1.34(\mathrm{~s}, 9 \mathrm{H}$, $\left.\mathrm{CH}_{3},{ }^{\mathrm{t}} \mathrm{Bu}\right), 1.59\left(\mathrm{~s}, 3 \mathrm{H}, \mathrm{CH}_{3}\right), 1.62\left(\mathrm{~s}, 9 \mathrm{H}, \mathrm{CH}_{3},{ }^{\mathrm{t}} \mathrm{Bu}\right), 1.67(\mathrm{~s}, 3 \mathrm{H}$, $\mathrm{CH}_{3}$ ), $1.81-1.95$ (b, $2 \mathrm{H}, \mathrm{CH}_{2}$, cod), $1.95-2.03\left(\mathrm{~b}, 6 \mathrm{H}, \mathrm{CH}_{2}\right.$, cod), 2.18 (s, 3H, $\left.\mathrm{CH}_{3}\right), 2.24$ (s, 3H, $\left.\mathrm{CH}_{3}\right), 2.55$ (s, 3H, $\left.\mathrm{CH}_{3}, \mathrm{SMe}\right), 3.27$ (b, $1 \mathrm{H}, \mathrm{CH}=$, cod) $, 4.50(\mathrm{~b}, 1 \mathrm{H}, \mathrm{CH}=$, cod $), 4.72-4.73(\mathrm{~b}, 1 \mathrm{H}, \mathrm{CH}=$, cod), 4.92-4.93 (b, 1H, CH=, cod), 6.83-6.85 (m, 1H, CH=), 7.21 $(\mathrm{m}, 1 \mathrm{H}, \mathrm{CH}=), 7.32-7.42(\mathrm{~m}, 2 \mathrm{H}, \mathrm{CH}=), 7.51(\mathrm{~m}, 4 \mathrm{H}, \mathrm{CH}=), 7.55-$ $7.61(\mathrm{~m}, 3 \mathrm{H}, \mathrm{CH}=), 7.70(\mathrm{~m}, 10 \mathrm{H}, \mathrm{CH}=), 7.90\left(\mathrm{~d}, 1 \mathrm{H}, \mathrm{CH}=,{ }^{3} J_{\mathrm{H}-\mathrm{H}}=\right.$ $9.0 \mathrm{~Hz}), 7.97\left(\mathrm{~d}, 1 \mathrm{H}, \mathrm{CH}=,{ }^{3} J_{\mathrm{H}-\mathrm{H}}=8.6 \mathrm{~Hz}\right), 8.01(\mathrm{~d}, 1 \mathrm{H}, \mathrm{CH}=), 8.15$ $(\mathrm{m}, 2 \mathrm{H}, \mathrm{C}=) .{ }^{13} \mathrm{C}$ NMR $\left(100.6 \mathrm{MHz}, \mathrm{CDCl}_{3}\right), \delta: 16.2\left(\mathrm{CH}_{3}\right), 16.2$ $\left(\mathrm{CH}_{3}\right), 20.1\left(\mathrm{CH}_{3}\right), 20.3\left(\mathrm{CH}_{3}\right), 20.7\left(\mathrm{CH}_{3}, \mathrm{SMe}\right), 30.0\left(\mathrm{CH}_{2}, \mathrm{cod}\right)$, $30.9\left(\mathrm{CH}_{2}, \mathrm{cod}\right), 31.1\left(\mathrm{CH}_{2}, \mathrm{cod}\right), 32.1\left(\mathrm{CH}_{3},{ }^{\mathrm{t}} \mathrm{Bu}\right), 32.7\left(\mathrm{CH}_{3},{ }^{\mathrm{t}} \mathrm{Bu}\right)$, $33.8\left(\mathrm{CH}_{2}, \operatorname{cod}\right), 34.8\left(\mathrm{C},{ }^{\mathrm{t}} \mathrm{Bu}\right), 35.6\left(\mathrm{C},{ }^{\mathrm{t}} \mathrm{Bu}\right), 69.9(\mathrm{CH}=, \operatorname{cod}), 72.6$ $(\mathrm{CH}=, \operatorname{cod}), 98.0\left(\mathrm{~d}, \mathrm{CH}=\right.$, cod, $\left.J_{\mathrm{C}-\mathrm{P}}=15.3 \mathrm{~Hz}\right), 100.2(\mathrm{~d}, \mathrm{CH}=$, cod, $J_{\mathrm{C}-\mathrm{P}}=15.3 \mathrm{~Hz}$ ), 117.4-146.7 (aromatic carbons), 161.7 (q, C-B, $\mathrm{BAr}_{\mathrm{F}},{ }^{1} \mathrm{~J}_{\mathrm{C}-\mathrm{B}}=49.7 \mathrm{~Hz}$ ). Anal. Calcd (\%) for $\mathrm{C}_{85} \mathrm{H}_{71} \mathrm{BF}_{4} \mathrm{IrO}_{3} \mathrm{PS}$ : C 54.81, H 3.84, S 1.72. Found: C 54.75, H 3.84, S 1.72. MS HR-ESI [found 999.3542, $\mathrm{C}_{53} \mathrm{H}_{59} \mathrm{IrO}_{3} \mathrm{PS}(\mathrm{M})^{+}$requires 999.3546].

$[\operatorname{Ir}(\mathrm{cod})(\mathrm{L2})] \mathrm{BAr}_{\mathrm{F}}$. Yield: $62 \mathrm{mg}(89 \%) .{ }^{31} \mathrm{P}$ NMR $(161.9 \mathrm{MHz}$, $\mathrm{CDCl}_{3}$ ), $\delta: 95.3$ (s). ${ }^{1} \mathrm{H}$ NMR (400 MHz, $\left.\mathrm{CDCl}_{3}\right), \delta: 0.69(\mathrm{~s}, 9 \mathrm{H}$, $\left.\mathrm{CH}_{3},{ }^{\mathrm{t}} \mathrm{Bu}\right), 1.48$ (s, $\left.9 \mathrm{H}, \mathrm{CH}_{3},{ }^{\mathrm{t}} \mathrm{Bu}\right), 1.69\left(\mathrm{~m}, 2 \mathrm{H}, \mathrm{CH}_{2}, \mathrm{cod}\right), 1.82$ (s, $\left.3 \mathrm{H}, \mathrm{CH}_{3}\right), 1.84\left(\mathrm{~s}, 3 \mathrm{H}, \mathrm{CH}_{3}\right), 2.00\left(\mathrm{~b}, 3 \mathrm{H}, \mathrm{CH}_{2}, \mathrm{cod}\right), 2.08-2.13(\mathrm{~b}$, $\left.2 \mathrm{H}, \mathrm{CH}_{2}, \mathrm{cod}\right), 2.24\left(\mathrm{~s}, 3 \mathrm{H}, \mathrm{CH}_{3}\right), 2.31\left(\mathrm{~s}, 3 \mathrm{H}, \mathrm{CH}_{3}\right), 2.33-2.38(\mathrm{~b}$, $\left.1 \mathrm{H}, \mathrm{CH}_{2}, \operatorname{cod}\right), 2.69\left(\mathrm{~s}, 3 \mathrm{H}, \mathrm{CH}_{3}, \mathrm{SMe}\right), 2.97(\mathrm{~b}, 1 \mathrm{H}, \mathrm{CH}=, \mathrm{cod})$, $4.51(\mathrm{~b}, 1 \mathrm{H}, \mathrm{CH}=$, cod), $5.32(\mathrm{~b}, 2 \mathrm{H}, \mathrm{CH}=$, cod), $7.01-7.09(\mathrm{~m}, 3 \mathrm{H}$, $\mathrm{C}=), 7.17\left(\mathrm{~d}, 1 \mathrm{H}, \mathrm{CH}=,{ }^{3} \mathrm{~J}_{\mathrm{H}-\mathrm{H}}=9.1 \mathrm{~Hz}\right), 7.27(\mathrm{~b}, 1 \mathrm{H}, \mathrm{CH}=), 7.34-$ $7.37(\mathrm{~m}, 2 \mathrm{H}, \mathrm{CH}=), 7.52(\mathrm{~m}, 5 \mathrm{H}, \mathrm{CH}=), 7.61-7.65(\mathrm{~m}, 1 \mathrm{H}, \mathrm{CH}=)$, $7.71(\mathrm{~m}, 8 \mathrm{H}, \mathrm{CH}=), 7.77\left(\mathrm{~d}, 1 \mathrm{H}, \mathrm{CH}={ }^{3} J_{\mathrm{H}-\mathrm{H}}=8.8 \mathrm{~Hz}\right), 7.89(\mathrm{~d}, 1 \mathrm{H}$, $\left.\mathrm{CH}={ }^{3} J_{\mathrm{H}-\mathrm{H}}=9.0 \mathrm{~Hz}\right), 7.94\left(\mathrm{~d}, 1 \mathrm{H}, \mathrm{CH}=,{ }^{3} J_{\mathrm{H}-\mathrm{H}}=8.1 \mathrm{~Hz}\right), 8.00(\mathrm{~d}$, $\left.1 \mathrm{H}, \mathrm{CH}=,{ }^{3} J_{\mathrm{H}-\mathrm{H}}=8.1 \mathrm{~Hz}\right), 8.14\left(\mathrm{~d}, 1 \mathrm{H}, \mathrm{CH},{ }^{3} \mathrm{~J}_{\mathrm{H}-\mathrm{H}}=8.8 \mathrm{~Hz}\right) .{ }^{13} \mathrm{C}$ NMR $\left(100.6 \mathrm{MHz}, \mathrm{CDCl}_{3}\right), \delta: 16.3\left(\mathrm{CH}_{3}\right), 16.6\left(\mathrm{CH}_{3}\right), 16.8\left(\mathrm{CH}_{3}\right.$, $\mathrm{SMe}), 20.3\left(\mathrm{CH}_{3}\right), 20.5\left(\mathrm{CH}_{3}\right), 28.7\left(\mathrm{CH}_{2}, \operatorname{cod}\right), 30.2\left(\mathrm{CH}_{2}, \mathrm{cod}\right)$, 31.0 $\left(\mathrm{CH}_{3},{ }^{\mathrm{t}} \mathrm{Bu}\right), 31.9\left(\mathrm{CH}_{2}, \mathrm{cod}\right), 32.5\left(\mathrm{CH}_{3},{ }^{\mathrm{t}} \mathrm{Bu}\right), 32.7\left(\mathrm{CH}_{2}, \mathrm{cod}\right)$, $34.4\left(\mathrm{C},{ }^{\mathrm{t}} \mathrm{Bu}\right), 35.1\left(\mathrm{C},{ }^{\mathrm{t}} \mathrm{Bu}\right), 69.9(\mathrm{CH}=, \mathrm{cod}), 78.6(\mathrm{CH}=, \mathrm{cod}), 97.1$ $\left(\mathrm{d}, \mathrm{CH}=\right.$, cod, $\left.J_{\mathrm{C}-\mathrm{P}}=18.3 \mathrm{~Hz}\right), 98.5\left(\mathrm{~d}, \mathrm{CH}=\right.$, cod, $\left.J_{\mathrm{C}-\mathrm{P}}=14.5 \mathrm{~Hz}\right)$, 117.4-147.3 (aromatic carbons), 161.7 (q, C-B, BAr ${ }_{\mathrm{F}},{ }^{1} J_{\mathrm{C}-\mathrm{B}}=49.7$ $\mathrm{Hz}$ ). Anal. Calcd (\%) for $\mathrm{C}_{85} \mathrm{H}_{71} \mathrm{BF}_{4} \mathrm{IrO}_{3} \mathrm{PS}$ : C 54.81, H 3.84, S 1.72 . Found: C 54.63, H 3.82, S 1.71. MS HR-ESI [found 999.3544, $\mathrm{C}_{53} \mathrm{H}_{59} \mathrm{IrO}_{3} \mathrm{PS}(\mathrm{M})^{+}$requires 999.3546].

[Ir(cod)(L3)]BAr . Yield: $64 \mathrm{mg}(91 \%) .{ }^{31} \mathrm{P}$ NMR $(161.9 \mathrm{MHz}$, $\mathrm{CDCl}_{3}$ ), $\delta: 92.1$ (s). ${ }^{1} \mathrm{H}$ NMR (400 MHz, $\mathrm{CDCl}_{3}$ ), $\delta: 0.67$ (s, 9H, $\left.\mathrm{CH}_{3},{ }^{\mathrm{t}} \mathrm{Bu}\right), 0.99-1.01\left(\mathrm{~m}, 6 \mathrm{H}, \mathrm{CH}_{2}, \mathrm{~S}^{\mathrm{i}} \mathrm{Pr}\right), 1.51\left(\mathrm{~s}, 9 \mathrm{H}, \mathrm{CH}_{3},{ }^{\mathrm{t}} \mathrm{Bu}\right)$, $1.72-1.77\left(\mathrm{~m}, 2 \mathrm{H}, \mathrm{CH}_{2}, \mathrm{cod}\right), 1.84\left(\mathrm{~s}, 3 \mathrm{H}, \mathrm{CH}_{3}\right), 1.85\left(\mathrm{~s}, 3 \mathrm{H}, \mathrm{CH}_{3}\right)$, 2.03-2.13 (b, $\left.3 \mathrm{H}, \mathrm{CH}_{2}, \mathrm{cod}\right), 2.24\left(\mathrm{~s}, 3 \mathrm{H}, \mathrm{CH}_{3}\right), 2.32\left(\mathrm{~s}, 3 \mathrm{H}, \mathrm{CH}_{3}\right)$, 2.39-2.47 (b, 3H, $\left.\mathrm{CH}_{2}, \mathrm{cod}\right), 3.10(\mathrm{~b}, 1 \mathrm{H}, \mathrm{CH}=, \mathrm{cod}), 3.90-3.97(\mathrm{~m}$, $\left.1 \mathrm{H}, \mathrm{CH},{ }^{\mathrm{i}} \mathrm{Pr}\right), 4.34(\mathrm{~b}, 1 \mathrm{H}, \mathrm{CH}=$, cod), $5.56(\mathrm{~b}, 2 \mathrm{H}, \mathrm{CH}=$, cod), $7.03-7.07(\mathrm{~m}, 3 \mathrm{H}, \mathrm{CH}=), 7.11\left(\mathrm{~d}, 1 \mathrm{H}, \mathrm{CH}=,{ }^{3} \mathrm{~J}_{\mathrm{H}-\mathrm{H}}=9.1 \mathrm{~Hz}\right) 7.29(\mathrm{~s}$, $1 \mathrm{H}, \mathrm{CH}=), 7.34-7.36(\mathrm{~m}, 2 \mathrm{H}, \mathrm{CH}=), 7.49-7.52(\mathrm{~m}, 5 \mathrm{H}, \mathrm{CH}=), 7.64$ $\left(\mathrm{t}, 1 \mathrm{H}, \mathrm{CH}=,{ }^{3} J_{\mathrm{H}-\mathrm{H}}=7.4 \mathrm{~Hz}\right), 7.72(\mathrm{~m}, 8 \mathrm{H}, \mathrm{CH}=), 7.78(\mathrm{~d}, 1 \mathrm{H}, \mathrm{CH}=$, $\left.{ }^{3} J_{\mathrm{H}-\mathrm{H}}=8.7 \mathrm{~Hz}\right), 7.87\left(\mathrm{~d}, 1 \mathrm{H}, \mathrm{CH}=,{ }^{3} J_{\mathrm{H}-\mathrm{H}}=9.0 \mathrm{~Hz}\right), 7.93(\mathrm{~d}, 1 \mathrm{H}, \mathrm{C}=$, $\left.{ }^{3} J_{\mathrm{H}-\mathrm{H}}=8.2 \mathrm{~Hz}\right), 8.00\left(\mathrm{~d}, 1 \mathrm{H}, \mathrm{CH}=,{ }^{3} J_{\mathrm{H}-\mathrm{H}}=8.1 \mathrm{~Hz}\right), 8.12(\mathrm{~d}, 1 \mathrm{H}$, $\left.\mathrm{CH}=,{ }^{3} J_{\mathrm{H}-\mathrm{H}}=8.7 \mathrm{~Hz}\right) .{ }^{13} \mathrm{C} \mathrm{NMR}\left(100.6 \mathrm{MHz}, \mathrm{CDCl}_{3}\right), \delta: 16.3$ $\left(\mathrm{CH}_{3}\right), 16.6\left(\mathrm{CH}_{3}\right), 20.3\left(\mathrm{CH}_{3}\right), 20.5\left(\mathrm{CH}_{3}\right), 22.5\left(\mathrm{CH}_{3}, \mathrm{~S} \mathrm{Pr}\right), 22.7$ $\left(\mathrm{CH}_{3}, \mathrm{~S}\right.$ Pr $), 29.2\left(\mathrm{CH}_{2}, \mathrm{cod}\right), 29.9\left(\mathrm{CH}_{2}, \operatorname{cod}\right), 31.0\left(\mathrm{CH}_{3},{ }^{\mathrm{t}} \mathrm{Bu}\right), 31.6$ $\left(\mathrm{CH}_{2}, \operatorname{cod}\right), 32.8\left(\mathrm{CH}_{3},{ }^{\mathrm{t}} \mathrm{Bu}\right), 33.0\left(\mathrm{CH}_{2}, \mathrm{cod}\right), 34.4\left(\mathrm{C},{ }^{\mathrm{t}} \mathrm{Bu}\right), 35.2$ (C, $\left.{ }^{t} \mathrm{Bu}\right), 37.7\left(\mathrm{CH}, \mathrm{S}^{\mathrm{i}} \mathrm{Pr}\right), 69.1(\mathrm{CH}=$, cod $), 75.9(\mathrm{CH}=$, cod), 97.9 $\left(\mathrm{d}, \mathrm{CH}=\right.$, cod, $\left.J_{\mathrm{C}-\mathrm{P}}=17.7 \mathrm{~Hz}\right), 98.8\left(\mathrm{~d}, \mathrm{CH}=\right.$, cod, $\left.J_{\mathrm{C}-\mathrm{P}}=14.3 \mathrm{~Hz}\right)$, 117.4-147.6 (aromatic carbons), 161.7 (q, C-B, BAr $_{\mathrm{F}},{ }^{1} J_{\mathrm{C}-\mathrm{B}}=50.0$ $\mathrm{Hz}$ ). Anal. Calcd (\%) for $\mathrm{C}_{87} \mathrm{H}_{75} \mathrm{BF}_{4} \mathrm{IrO}_{3} \mathrm{PS}$ : C 55.27, H 4.00, S 1.70 . Found: C 55.11, H 3.98, S 1.69. MS HR-ESI [found 1027.3854, $\mathrm{C}_{55} \mathrm{H}_{63} \mathrm{IrO}_{3} \mathrm{PS}(\mathrm{M})^{+}$requires 1027.3859].

$[\operatorname{Ir}(\operatorname{cod})(\mathrm{L} 5)] \mathrm{BAr}_{\mathrm{F}}$. Yield: $63 \mathrm{mg}(88 \%) .{ }^{31} \mathrm{P}$ NMR $(161.9 \mathrm{MHz}$, $\mathrm{CDCl}_{3}$ ), $\delta: 91.9$ (s). ${ }^{1} \mathrm{H}$ NMR (400 $\left.\mathrm{MHz}, \mathrm{CDCl}_{3}\right), \delta: 0.67$ (s, 9H, $\left.\mathrm{CH}_{3},{ }^{\mathrm{t}} \mathrm{Bu}\right), 0.73\left(\mathrm{~m}, 1 \mathrm{H}, \mathrm{CH}_{2}, \mathrm{SCy}\right), 0.87-0.90\left(\mathrm{~m}, 4 \mathrm{H}, \mathrm{CH}_{2}, \mathrm{SCy}\right)$, 1.26 (m, 5H, SCy), 1.50 (s, 9H, $\left.\mathrm{CH}_{3},{ }^{\mathrm{t}} \mathrm{Bu}\right), 1.64-1.68\left(\mathrm{~m}, 1 \mathrm{H}, \mathrm{CH}_{2}\right.$, cod), $1.84\left(\mathrm{~s}, 3 \mathrm{H}, \mathrm{CH}_{3}\right), 1.85\left(\mathrm{~s}, 3 \mathrm{H}, \mathrm{CH}_{3}\right), 1.98-2.12\left(\mathrm{~b}, 4 \mathrm{H}, \mathrm{CH}_{2}\right.$, cod), 2.24 (s, $\left.3 \mathrm{H}, \mathrm{CH}_{3}\right), 2.32\left(\mathrm{~s}, 3 \mathrm{H}, \mathrm{CH}_{3}\right), 2.40-2.47\left(\mathrm{~m}, 3 \mathrm{H}, \mathrm{CH}_{2}\right.$, cod), 3.10 (b, $1 \mathrm{H}, \mathrm{CH}=$, cod), 3.73 (b, 1H, CH, SCy), 4.30-4.32 (b, $1 \mathrm{H}, \mathrm{CH}=$, cod), $5.58(\mathrm{~b}, 2 \mathrm{H}, \mathrm{CH}=$, cod), $7.05-7.06(\mathrm{~m}, 3 \mathrm{H}, \mathrm{CH}=)$, $7.11\left(\mathrm{~d}, 1 \mathrm{H}, \mathrm{CH}=,{ }^{3} J_{\mathrm{H}-\mathrm{H}}=9.1 \mathrm{~Hz}\right), 7.28(\mathrm{~m}, 1 \mathrm{H}, \mathrm{CH}=), 7.31-37(\mathrm{~m}$, $2 \mathrm{H}, \mathrm{CH}=), 7.47-7.52(\mathrm{~m}, 5 \mathrm{H}, \mathrm{CH}=), 7.62\left(\mathrm{t}, 1 \mathrm{H}, \mathrm{CH}={ }^{3} J_{\mathrm{H}-\mathrm{H}}=7.4\right.$ $\mathrm{Hz}), 7.73(\mathrm{~m}, 8 \mathrm{H}, \mathrm{CH}=), 7.78\left(\mathrm{~d}, 1 \mathrm{H}, \mathrm{CH}=,{ }^{3} J_{\mathrm{H}-\mathrm{H}}=8.8 \mathrm{~Hz}\right), 7.86(\mathrm{~d}$, $\left.1 \mathrm{H}, \mathrm{CH}=,{ }^{3} J_{\mathrm{H}-\mathrm{H}}=9.1 \mathrm{~Hz}\right), 7.92\left(\mathrm{~d}, 1 \mathrm{H}, \mathrm{C}=,{ }^{3} J_{\mathrm{H}-\mathrm{H}}=8.3 \mathrm{~Hz}\right), 7.99(\mathrm{~d}$, $\left.1 \mathrm{H}, \mathrm{CH}=,{ }^{3} J_{\mathrm{H}-\mathrm{H}}=8.1 \mathrm{~Hz}\right), 8.10\left(\mathrm{~d}, 1 \mathrm{H}, \mathrm{CH}=,{ }^{3} J_{\mathrm{H}-\mathrm{H}}=8.7 \mathrm{~Hz}\right) .{ }^{13} \mathrm{C}$ $\operatorname{NMR}\left(100.6 \mathrm{MHz}, \mathrm{CDCl}_{3}\right), \delta: 16.3\left(\mathrm{CH}_{3}\right), 16.6\left(\mathrm{CH}_{3}\right), 20.3\left(\mathrm{CH}_{3}\right)$, $20.5\left(\mathrm{CH}_{3}\right), 22.7\left(\mathrm{CH}_{2}, \mathrm{SCy}\right), 24.6\left(\mathrm{CH}_{2}, \mathrm{SCy}\right), 25.0\left(\mathrm{CH}_{2}, \mathrm{SCy}\right)$, $25.5\left(\mathrm{CH}_{2}, \mathrm{SCy}\right), 29.1\left(\mathrm{CH}_{2}, \operatorname{cod}\right), 29.9\left(\mathrm{CH}_{2}, \mathrm{cod}\right), 31.0\left(\mathrm{CH}_{3},{ }^{\mathrm{t}} \mathrm{Bu}\right)$, $31.7\left(\mathrm{CH}_{2}, \mathrm{cod}\right), 32.0\left(\mathrm{CH}_{2}, \operatorname{cod}\right), 32.8\left(\mathrm{CH}_{3},{ }^{\mathrm{t}} \mathrm{Bu}\right), 34.4\left(\mathrm{C},{ }^{\mathrm{t}} \mathrm{Bu}\right)$, $35.2\left(\mathrm{C},{ }^{\mathrm{t}} \mathrm{Bu}\right), 46.0(\mathrm{CH}, \mathrm{SCy}), 68.8(\mathrm{CH}=$, cod $), 75.6(\mathrm{CH}=$, cod $)$, $98.0\left(\mathrm{~d}, \mathrm{CH}=\right.$, cod, $\left.J_{\mathrm{C}-\mathrm{P}}=17.8 \mathrm{~Hz}\right), 98.8\left(\mathrm{~d}, \mathrm{CH}=\right.$, cod, $J_{\mathrm{C}-\mathrm{P}}=14.7$ $\mathrm{Hz}), 117.4-147.8$ (aromatic carbons), 161.7 (q, C-B, $\mathrm{BAr}_{\mathrm{F}},{ }^{1} J_{\mathrm{C}-\mathrm{B}}=$ $49.9 \mathrm{~Hz}$ ). Anal. Calcd (\%) for $\mathrm{C}_{90} \mathrm{H}_{79} \mathrm{BF}_{4} \mathrm{IrO}_{3}$ PS: C 55.99, H 4.12, S 1.66. Found: C 55.73, H 4.10, S 1.65. MS HR-ESI [found 1067.4167, $\mathrm{C}_{58} \mathrm{H}_{67} \mathrm{IrO}_{3} \mathrm{PS}(\mathrm{M})^{+}$requires 1067.4172$]$.

[Ir(cod)(L6)BAr ${ }_{\mathrm{F}}$. Yield: $64 \mathrm{mg}(90 \%) .{ }^{31} \mathrm{P}$ NMR $(161.9 \mathrm{MHz}$, $\mathrm{CDCl}_{3}$ ), $\delta: 98.7$ (s). ${ }^{1} \mathrm{H}$ NMR (400 $\left.\mathrm{MHz}, \mathrm{CDCl}_{3}\right), \delta: 0.74$ (s, 9H, $\left.\mathrm{CH}_{3},{ }^{\mathrm{t}} \mathrm{Bu}\right), 1.31\left(\mathrm{~s}, 9 \mathrm{H}, \mathrm{CH}_{3},{ }^{\mathrm{t}} \mathrm{Bu}\right), 1.37\left(\mathrm{~s}, 9 \mathrm{H}, \mathrm{CH}_{3},{ }^{\mathrm{t}} \mathrm{Bu}\right), 1.54(\mathrm{~s}$, $\left.9 \mathrm{H}, \mathrm{CH}_{3},{ }^{\mathrm{t}} \mathrm{Bu}\right), 1.74-1.79$ (b, $\left.2 \mathrm{H}, \mathrm{CH}_{2}, \mathrm{cod}\right), 2.10-2.25(\mathrm{~b}, 5 \mathrm{H}$, $\left.\mathrm{CH}_{2}, \mathrm{cod}\right), 2.36-2.38$ (b, $\left.1 \mathrm{H}, \mathrm{CH}_{2}, \mathrm{cod}\right), 2.71$ (s, 3H, SMe), 3.43 (b, $1 \mathrm{H}, \mathrm{CH}=$, cod), $4.60(\mathrm{~b}, 1 \mathrm{H}, \mathrm{CH}=$, cod), $5.33(\mathrm{~b}, 1 \mathrm{H}, \mathrm{CH}=$, cod), $5.40(\mathrm{~b}, 1 \mathrm{H}, \mathrm{CH}=$, cod), 7.04-7.11 (m, 2H, C=), $7.16(\mathrm{~m}, 1 \mathrm{H}$, $\mathrm{CH}=), 7.23(\mathrm{~m}, 1 \mathrm{H}, \mathrm{CH}=), 7.29(\mathrm{~s}, 1 \mathrm{H}, \mathrm{CH}=), 7.31-7.32(\mathrm{~m}, 1 \mathrm{H}$, $\mathrm{CH}=)$, 7.35-7.39 (m, 2H, CH=), $7.52(\mathrm{~b}, 5 \mathrm{H}, \mathrm{CH}=), 7.58-7.59(\mathrm{~m}$, $1 \mathrm{H}, \mathrm{CH}=)$, 7.62-7.66 (m, 1H, CH=), $7.71(\mathrm{~m}, 8 \mathrm{H}, \mathrm{CH}=), 7.78(\mathrm{~d}$, $\left.1 \mathrm{H}, \mathrm{CH}=,{ }^{3} J_{\mathrm{H}-\mathrm{H}}=8.8 \mathrm{~Hz}\right), 7.89\left(\mathrm{~d}, 1 \mathrm{H}, \mathrm{CH}=,{ }^{3} J_{\mathrm{H}-\mathrm{H}}=9.0 \mathrm{~Hz}\right), 7.94$ $\left(\mathrm{d}, 1 \mathrm{H}, \mathrm{CH}=,{ }^{3} J_{\mathrm{H}-\mathrm{H}}=8.1 \mathrm{~Hz}\right), 8.01\left(\mathrm{~d}, 1 \mathrm{H}, \mathrm{CH}=,{ }^{3} J_{\mathrm{H}-\mathrm{H}}=8.2 \mathrm{~Hz}\right)$, $8.15\left(\mathrm{~d}, 1 \mathrm{H}, \mathrm{CH}=,{ }^{3} J_{\mathrm{H}-\mathrm{H}}=8.7 \mathrm{~Hz}\right) .{ }^{13} \mathrm{C} \mathrm{NMR}\left(100.6 \mathrm{MHz}, \mathrm{CDCl}_{3}\right)$, $\delta: 16.9\left(\mathrm{CH}_{3}, \mathrm{SMe}\right), 28.6\left(\mathrm{CH}_{2}, \mathrm{cod}\right), 29.7\left(\mathrm{CH}_{2}, \mathrm{cod}\right), 30.8\left(\mathrm{CH}_{3}\right.$, $\left.{ }^{\mathrm{t}} \mathrm{Bu}\right), 31.3\left(\mathrm{CH}_{3},{ }^{\mathrm{t}} \mathrm{Bu}\right), 31.4\left(\mathrm{CH}_{3},{ }^{\mathrm{t}} \mathrm{Bu}\right), 31.5\left(\mathrm{CH}_{2}, \mathrm{cod}\right), 32.5\left(\mathrm{CH}_{3}\right.$, $\left.{ }^{\mathrm{t}} \mathrm{Bu}\right), 32.9\left(\mathrm{CH}_{2}, \mathrm{cod}\right), 34.8\left(\mathrm{C},{ }^{\mathrm{t}} \mathrm{Bu}\right), 34.9\left(\mathrm{C},{ }^{\mathrm{t}} \mathrm{Bu}\right), 35.0\left(\mathrm{C},{ }^{\mathrm{t}} \mathrm{Bu}\right)$, $35.9\left(\mathrm{C},{ }^{\mathrm{t}} \mathrm{Bu}\right), 69.8(\mathrm{CH}=$, cod $), 78.8(\mathrm{CH}=, \mathrm{cod}), 97.4(\mathrm{~d}, \mathrm{CH}=$, cod, $\left.J_{\text {C-P }}=17.5 \mathrm{~Hz}\right), 98.8\left(\mathrm{~d}, \mathrm{CH}=\right.$, cod, $\left.J_{\mathrm{C}-\mathrm{P}}=14.8 \mathrm{~Hz}\right), 117.4-149.3$ (aromatic carbons), 161.7 (q, C-B, $\mathrm{BAr}_{\mathrm{F}},{ }^{1} \mathrm{~J}_{\mathrm{C}-\mathrm{B}}=49.4 \mathrm{~Hz}$ ). Anal. Calcd (\%) for $\mathrm{C}_{89} \mathrm{H}_{79} \mathrm{BF}_{4} \mathrm{IrO}_{3}$ PS: C 55.72, $\mathrm{H} 4.15$, S 1.67. Found: C 55.60, H 4.14, S 1.67. MS HR-ESI [found 1055.4170, $\mathrm{C}_{57} \mathrm{H}_{67} \mathrm{IrO}_{3} \mathrm{PS}$ $(\mathrm{M})^{+}$requires 1055.4172$]$.

$[\operatorname{Ir}(\operatorname{cod})(\mathrm{L} 7)] \mathrm{BAr}_{\mathrm{F}}$. Yield: $67 \mathrm{mg}(93 \%) .{ }^{31} \mathrm{P}$ NMR $(161.9 \mathrm{MHz}$, $\left.\mathrm{CDCl}_{3}\right), \delta: 95.6$ (s). ${ }^{1} \mathrm{H}$ NMR (400 $\left.\mathrm{MHz}, \mathrm{CDCl}_{3}\right), \delta: 0.74(\mathrm{~s}, 9 \mathrm{H}$, $\left.\mathrm{CH}_{3},{ }^{\mathrm{t}} \mathrm{Bu}\right), 1.03-1.05\left(\mathrm{~m}, 6 \mathrm{H}, \mathrm{CH}_{3}, \mathrm{~S}^{\mathrm{i}} \mathrm{Pr}\right), 1.32\left(\mathrm{~s}, 9 \mathrm{H}, \mathrm{CH}_{3},{ }^{\mathrm{t}} \mathrm{Bu}\right)$, $1.39\left(\mathrm{~s}, 9 \mathrm{H}, \mathrm{CH}_{3},{ }^{\mathrm{t}} \mathrm{Bu}\right), 1.56\left(\mathrm{~s}, 9 \mathrm{H}, \mathrm{CH}_{3},{ }^{\mathrm{t}} \mathrm{Bu}\right), 1.78-1.90(\mathrm{~b}, 4 \mathrm{H}$, $\mathrm{CH}_{2}$, cod), 2.08-2.11 (m, $2 \mathrm{H}, \mathrm{CH}_{2}$, cod), 2.39-2.51 (m, $2 \mathrm{H}, \mathrm{CH}_{2}$, cod), $3.56\left(\mathrm{~b}, 1 \mathrm{H}, \mathrm{CH}=\right.$, cod), 3.94-3.97 (m, 1H, CH, $\left.{ }^{\mathrm{i}} \mathrm{Pr}\right), 4.41-$ $4.44(\mathrm{~b}, 1 \mathrm{H}, \mathrm{CH}=$, cod), $5.57(\mathrm{~b}, 1 \mathrm{H}, \mathrm{CH}=$, cod), $5.64(\mathrm{~b}, 1 \mathrm{H}, \mathrm{CH}=$, cod), $7.05\left(\mathrm{~d}, 1 \mathrm{H}, \mathrm{CH}=,{ }^{3} J_{\mathrm{H}-\mathrm{H}}=8.5 \mathrm{~Hz}\right), 7.09\left(\mathrm{~d}, 1 \mathrm{H}, \mathrm{CH}=,{ }^{3} J_{\mathrm{H}-\mathrm{H}}=\right.$ $8.5 \mathrm{~Hz}), 7.19-7.27(\mathrm{~m}, 3 \mathrm{H}, \mathrm{CH}=), 7.33-7.38(\mathrm{~m}, 4 \mathrm{H}, \mathrm{CH}=), 7.53$ $(\mathrm{m}, 4 \mathrm{H}, \mathrm{CH}=), 7.60(\mathrm{~s}, 1 \mathrm{H}, \mathrm{CH}=), 7.63-7.67(\mathrm{~m}, 1 \mathrm{H}, \mathrm{CH}=), 7.72$ $(\mathrm{m}, 8 \mathrm{H}, \mathrm{CH}=), 7.80\left(\mathrm{~d}, 1 \mathrm{H}, \mathrm{CH}=,{ }^{3} \mathrm{~J}_{\mathrm{H}-\mathrm{H}}=8.7 \mathrm{~Hz}\right), 7.87(\mathrm{~d}, 1 \mathrm{H}, \mathrm{CH}=$, $\left.{ }^{3} J_{\mathrm{H}-\mathrm{H}}=9.1 \mathrm{~Hz}\right), 7.93\left(\mathrm{~d}, 1 \mathrm{H}, \mathrm{C}=,{ }^{3} J_{\mathrm{H}-\mathrm{H}}=8.3 \mathrm{~Hz}\right), 8.01(\mathrm{~d}, 1 \mathrm{H}, \mathrm{CH}=$, $\left.{ }^{3} J_{\mathrm{H}-\mathrm{H}}=8.1 \mathrm{~Hz}\right), 8.13\left(\mathrm{~d}, 1 \mathrm{H}, \mathrm{CH}=,{ }^{3} J_{\mathrm{H}-\mathrm{H}}=8.7 \mathrm{~Hz}\right) .{ }^{13} \mathrm{C} \mathrm{NMR}(100.6$ $\left.\mathrm{MHz}, \mathrm{CDCl}_{3}\right), \delta: 21.4\left(\mathrm{CH}_{3}, \mathrm{~S} \mathrm{Pr}\right), 22.4\left(\mathrm{CH}_{3}, \mathrm{~S} \mathrm{Pr}\right), 29.4\left(\mathrm{CH}_{2}\right.$, cod), $29.7\left(\mathrm{CH}_{2}, \operatorname{cod}\right), 30.8\left(\mathrm{CH}_{3},{ }^{t} \mathrm{Bu}\right), 31.3\left(\mathrm{CH}_{3},{ }^{\mathrm{t}} \mathrm{Bu}\right), 31.4\left(\mathrm{CH}_{3}\right.$, $\left.{ }^{\mathrm{t}} \mathrm{Bu}\right), 31.4\left(\mathrm{CH}_{2}, \mathrm{cod}\right), 31.5\left(\mathrm{CH}_{2}, \mathrm{cod}\right), 32.6\left(\mathrm{CH}_{3},{ }^{\mathrm{t}} \mathrm{Bu}\right), 34.8(\mathrm{C}$, $\left.{ }^{\mathrm{t}} \mathrm{Bu}\right), 34.9\left(\mathrm{C},{ }^{\mathrm{t}} \mathrm{Bu}\right), 35.1\left(\mathrm{C},{ }^{\mathrm{t}} \mathrm{Bu}\right), 35.9\left(\mathrm{C},{ }^{\mathrm{t}} \mathrm{Bu}\right), 37.7\left(\mathrm{CH}, \mathrm{S}^{\mathrm{i}} \mathrm{Pr}\right)$, $69.2\left(\mathrm{CH}=\right.$, cod), $75.9(\mathrm{CH}=$, cod $), 98.2\left(\mathrm{~d}, \mathrm{CH}=\right.$, cod, $J_{\mathrm{C}-\mathrm{p}}=19.8$ $\mathrm{Hz}), 99.3\left(\mathrm{~d}, \mathrm{CH}=\right.$, cod, $\left.J_{\mathrm{C}-\mathrm{P}}=13.7 \mathrm{~Hz}\right), 115.4-149.3$ (aromatic 
carbons), 161.7 (q, C-B, $\mathrm{BAr}_{\mathrm{F}},{ }^{1} J_{\mathrm{C}-\mathrm{B}}=50.5 \mathrm{~Hz}$ ). Anal. Calcd (\%) for $\mathrm{C}_{91} \mathrm{H}_{83} \mathrm{BF}_{4} \mathrm{IrO}_{3} \mathrm{PS}$ : C 56.15, H 4.30, S 1.65. Found: C 56.01, H 4.28, $\mathrm{S}$ 1.64. MS HR-ESI [found 1083.4482, $\mathrm{C}_{59} \mathrm{H}_{71} \mathrm{IrO}_{3} \mathrm{PS}(\mathrm{M})^{+}$requires 1083.4485].

$[\operatorname{Ir}(\operatorname{cod})(\mathrm{L8})] \mathrm{BAr}_{\mathrm{F}}$. Yield: $64 \mathrm{mg}(88 \%) .{ }^{31} \mathrm{P}$ NMR $(161.9 \mathrm{MHz}$, $\mathrm{CDCl}_{3}$ ), $\delta: 96.5$ (s). ${ }^{1} \mathrm{H}$ NMR (400 MHz, $\mathrm{CDCl}_{3}$ ), $\delta: 0.68$ (s, 9H, $\left.\mathrm{CH}_{3},{ }^{\mathrm{t}} \mathrm{Bu}\right), 1.31\left(\mathrm{~s}, 9 \mathrm{H}, \mathrm{CH}_{3},{ }^{\mathrm{t}} \mathrm{Bu}\right), 1.39\left(\mathrm{~s}, 9 \mathrm{H}, \mathrm{CH}_{3},{ }^{\mathrm{t}} \mathrm{Bu}\right), 1.70(\mathrm{~s}$, $\left.9 \mathrm{H}, \mathrm{CH}_{3},{ }^{\mathrm{t}} \mathrm{Bu}\right), 1.84-1.90\left(\mathrm{~b}, 2 \mathrm{H}, \mathrm{CH}_{2}, \mathrm{cod}\right), 1.97-2.07(\mathrm{~b}, 2 \mathrm{H}$, $\mathrm{CH}_{2}$, cod), 2.24-2.33 (b, $2 \mathrm{H}, \mathrm{CH}_{2}$, cod), 2.39-2.43 (b, $2 \mathrm{H}, \mathrm{CH}_{2}$, cod), $3.45(\mathrm{~b}, 1 \mathrm{H}, \mathrm{CH}=$, cod), $4.44(\mathrm{~b}, 1 \mathrm{H}, \mathrm{CH}=$, cod), $4.76(\mathrm{~b}, 1 \mathrm{H}$, $\mathrm{CH}=$, cod), $5.30(\mathrm{~b}, 1 \mathrm{H}, \mathrm{CH}=, \operatorname{cod}), 7.14-7.21(\mathrm{~m}, 6 \mathrm{H}, \mathrm{CH}=)$, 7.32-7.48 (m, 9H, CH=), 7.51 (m, 4H, CH=), 7.63-7.64 (m, 1H, $\mathrm{CH}=), 7.70-7.72(\mathrm{~m}, 8 \mathrm{H}, \mathrm{CH}=), 7.90\left(\mathrm{~d}, 2 \mathrm{H}, \mathrm{CH}=,{ }^{3} J_{\mathrm{H}-\mathrm{H}}=8.8 \mathrm{~Hz}\right)$, $8.07-8.11(\mathrm{~m}, 2 \mathrm{H}, \mathrm{CH}=), 8.25\left(\mathrm{~d}, 1 \mathrm{H}, \mathrm{CH}=,{ }^{3} \mathrm{~J}_{\mathrm{H}-\mathrm{H}}=8.9 \mathrm{~Hz}\right) .{ }^{13} \mathrm{C}$ NMR (100.6 MHz, $\left.\mathrm{CDCl}_{3}\right), \delta: 28.2\left(\mathrm{CH}_{2}, \mathrm{cod}\right), 29.3\left(\mathrm{CH}_{2}, \mathrm{cod}\right)$, $30.8\left(\mathrm{CH}_{3},{ }^{\mathrm{t}} \mathrm{Bu}\right), 31.0\left(\mathrm{CH}_{2}, \mathrm{cod}\right), 31.3\left(\mathrm{CH}_{3},{ }^{\mathrm{t}} \mathrm{Bu}\right), 31.4\left(\mathrm{CH}_{3},{ }^{\mathrm{t}} \mathrm{Bu}\right)$, $31.6\left(\mathrm{CH}_{2}, \mathrm{cod}\right), 32.9\left(\mathrm{CH}_{3},{ }^{\mathrm{t}} \mathrm{Bu}\right), 34.8\left(\mathrm{C},{ }^{\mathrm{t}} \mathrm{Bu}\right), 34.9\left(\mathrm{C},{ }^{\mathrm{t}} \mathrm{Bu}\right), 35.0$ $\left(\mathrm{C},{ }^{\mathrm{t}} \mathrm{Bu}\right), 36.0\left(\mathrm{C},{ }^{\mathrm{t}} \mathrm{Bu}\right), 69.1(\mathrm{CH}=, \operatorname{cod}), 77.2(\mathrm{CH}=, \operatorname{cod}), 100.8$ $(\mathrm{CH}=$, cod), $101.7(\mathrm{CH}=$, cod), 117.4-149.5 (aromatic carbons), $161.7\left(\mathrm{q}, \mathrm{C}-\mathrm{B}, \mathrm{BAr}_{\mathrm{F}},{ }^{1} J_{\mathrm{C}-\mathrm{B}}=50.0 \mathrm{~Hz}\right)$. Anal. Calcd (\%) for $\mathrm{C}_{94} \mathrm{H}_{81} \mathrm{BF}_{4} \mathrm{IrO}_{3}$ PS: C 57.00, H 4.12, S 1.62. Found: C 56.88, H 4.10, S 1.62. MS HR-ESI [found 1117.4325, $\mathrm{C}_{62} \mathrm{H}_{69} \mathrm{IrO}_{3} \mathrm{PS}(\mathrm{M})^{+}$requires $1117.4329]$.

[Ir(cod)(L9)]BAr B $_{\text {F }}$ Yield: $64 \mathrm{mg}(87 \%) .{ }^{31} \mathrm{P}$ NMR (161.9 MHz, $\mathrm{CDCl}_{3}$ ), $\delta: 95.6(\mathrm{~s}) .{ }^{1} \mathrm{H}$ NMR $\left(400 \mathrm{MHz} \mathrm{CDCl}_{3}\right), \delta: 0.73(\mathrm{~s}, 9 \mathrm{H}$, $\left.\mathrm{CH}_{3}, \mathrm{t} \mathrm{Bu}\right), 0.79\left(\mathrm{~b}, 1 \mathrm{H}, \mathrm{CH}_{2}, \mathrm{SCy}\right), 1.08\left(\mathrm{~m}, 2 \mathrm{H}, \mathrm{CH}_{2}, \mathrm{SCy}\right), 1.31$ (s, $\left.9 \mathrm{H}, \mathrm{CH}_{3},{ }^{\mathrm{t}} \mathrm{Bu}\right), 1.34\left(\mathrm{~b}, 3 \mathrm{H}, \mathrm{CH}_{2}, \mathrm{SCy}\right), 1.38\left(\mathrm{~s}, 9 \mathrm{H}, \mathrm{CH}_{3},{ }^{\mathrm{t}} \mathrm{Bu}\right)$, $1.45-1.46\left(\mathrm{~m}, 3 \mathrm{H}, \mathrm{CH}_{2}, \mathrm{SCy}\right), 1.56\left(\mathrm{~s}, 9 \mathrm{H}, \mathrm{CH}_{3},{ }^{\mathrm{t}} \mathrm{Bu}\right), 1.62-1.71(\mathrm{~b}$, $3 \mathrm{H}, \mathrm{CH}_{2}$, cod and $\left.\mathrm{CH}_{2}, \mathrm{SCy}\right), 1.86-1.89\left(\mathrm{~b}, 2 \mathrm{H}, \mathrm{CH}_{2}, \mathrm{cod}\right) 2.09-$ 2.11 (b, $2 \mathrm{H}, \mathrm{CH}_{2}$, cod), 2.38-2.49 (b, $\left.2 \mathrm{H}, \mathrm{CH}_{2}, \mathrm{cod}\right), 3.54(\mathrm{~b}, 1 \mathrm{H}$, $\mathrm{CH}=$, cod), $3.74(\mathrm{~m}, 1 \mathrm{H}, \mathrm{CH}, \mathrm{SCy}), 4.37-4.41(\mathrm{~b}, 1 \mathrm{H}, \mathrm{CH}=$, cod $)$, $5.62(\mathrm{~b}, 2 \mathrm{H}, \mathrm{CH}=$, cod) $7.04-7.09(\mathrm{~m}, 2 \mathrm{H}, \mathrm{CH}=), 7.18-7.25(\mathrm{~m}$, $3 \mathrm{H}, \mathrm{CH}=), 7.32-7.38(\mathrm{~m}, 3 \mathrm{H}, \mathrm{CH}=), 7.48-7.52(\mathrm{~m}, 4 \mathrm{H}, \mathrm{CH}=)$, $7.58-7.59(\mathrm{~m}, 1 \mathrm{H}, \mathrm{CH}=), 7.62-7.66(\mathrm{~m}, 2 \mathrm{H}, \mathrm{CH}=), 7.72(\mathrm{~m}, 8 \mathrm{H}$, $\mathrm{CH}=), 7.80\left(\mathrm{~d}, 1 \mathrm{H}, \mathrm{CH}=,{ }^{3} J_{\mathrm{H}-\mathrm{H}}=8.8 \mathrm{~Hz}\right), 7.86\left(\mathrm{~d}, 1 \mathrm{H}, \mathrm{CH}=,{ }^{3} \mathrm{~J}_{\mathrm{H}-\mathrm{H}}=\right.$ $9.1 \mathrm{~Hz}), 7.92\left(\mathrm{~d}, 1 \mathrm{H}, \mathrm{C}=,{ }^{3} J_{\mathrm{H}-\mathrm{H}}=8.2 \mathrm{~Hz}\right), 8.00\left(\mathrm{~d}, 1 \mathrm{H}, \mathrm{CH}=,{ }^{3} J_{\mathrm{H}-\mathrm{H}}=\right.$ $8.3 \mathrm{~Hz}), 8.11\left(\mathrm{~d}, 1 \mathrm{H}, \mathrm{CH}=,{ }^{3} \mathrm{~J}_{\mathrm{H}-\mathrm{H}}=8.7 \mathrm{~Hz}\right) .{ }^{13} \mathrm{C}$ NMR $(100.6 \mathrm{MHz}$, $\left.\mathrm{CDCl}_{3}\right), \delta: 22.7\left(\mathrm{CH}_{2}, \mathrm{SCy}\right), 24.6\left(\mathrm{CH}_{2}, \mathrm{SCy}\right), 25.0\left(\mathrm{CH}_{2}, \mathrm{SCy}\right)$, $25.4\left(\mathrm{CH}_{2}, \mathrm{SCy}\right), 29.4\left(\mathrm{CH}_{2}, \mathrm{cod}\right), 29.8\left(\mathrm{CH}_{2}, \mathrm{cod}\right), 30.4\left(\mathrm{CH}_{2}\right.$, SCy), $30.8\left(\mathrm{CH}_{3},{ }^{t} \mathrm{Bu}\right), 31.3\left(\mathrm{CH}_{3},{ }^{\mathrm{t}} \mathrm{Bu}\right), 31.4\left(\mathrm{CH}_{3},{ }^{\mathrm{t}} \mathrm{Bu}\right), 31.7\left(\mathrm{CH}_{2}\right.$, cod), $32.1\left(\mathrm{CH}_{2}, \mathrm{cod}\right), 32.6\left(\mathrm{CH}_{3},{ }^{\mathrm{t}} \mathrm{Bu}\right), 34.8\left(\mathrm{C},{ }^{\mathrm{t}} \mathrm{Bu}\right), 34.9\left(\mathrm{C},{ }^{\mathrm{t}} \mathrm{Bu}\right)$, $35.0\left(\mathrm{C},{ }^{\mathrm{t}} \mathrm{Bu}\right), 35.9\left(\mathrm{C},{ }^{\mathrm{t}} \mathrm{Bu}\right), 46.0(\mathrm{CH}, \mathrm{SCy}), 68.9(\mathrm{CH}=$, cod $), 75.6$ $(\mathrm{CH}=, \mathrm{cod}), 98.3\left(\mathrm{~d}, \mathrm{CH}=\right.$, cod, $\left.J_{\mathrm{C}-\mathrm{P}}=17.9 \mathrm{~Hz}\right), 99.2(\mathrm{~d}, \mathrm{CH}=$, cod, $J_{\mathrm{C}-\mathrm{p}}=14.2 \mathrm{~Hz}$ ), 117.4-149.2 (aromatic carbons), 161.7 (q, C-B, $\mathrm{BAr}_{\mathrm{F}},{ }^{1} \mathrm{~J}_{\mathrm{C}-\mathrm{B}}=49.9 \mathrm{~Hz}$ ). Anal. Calcd (\%) for $\mathrm{C}_{94} \mathrm{H}_{87} \mathrm{BF}_{4} \mathrm{IrO}_{3} \mathrm{PS}$ : C 56.83, H 4.41, S 1.61. Found: C 56.65, H 4.40, S 1.60. MS HR-ESI [found 1123.4795, $\mathrm{C}_{62} \mathrm{H}_{75} \mathrm{IrO}_{3} \mathrm{PS}(\mathrm{M})^{+}$requires 1123.4798].

General Procedure for the Asymmetric Hydrogenation. The alkene $(0.25 \mathrm{mmol})$ and Ir complex $(1 \mathrm{~mol} \%)$ were dissolved in $\mathrm{CH}_{2} \mathrm{Cl}_{2}(2 \mathrm{~mL})$ and placed in a high-pressure autoclave. The autoclave was purged four times with hydrogen. Then, it was pressurized at the desired pressure. After the desired reaction time, the autoclave was depressurized and the solvent evaporated off. The residue was dissolved in $\mathrm{Et}_{2} \mathrm{O}(1.5 \mathrm{~mL})$ and filtered through a short plug of celite. The enantiomeric excess was determined by chiral GC or chiral HPLC (see the Supporting Information for details), and conversions were determined by ${ }^{1} \mathrm{H}$ NMR.

\section{ASSOCIATED CONTENT}

\section{(s) Supporting Information}

The Supporting Information is available free of charge at https://pubs.acs.org/doi/10.1021/acs.organomet.1c00450.

CartCoord contains the computed Cartesian coordinates of all of the molecules reported in this study (XYZ) Synthesis of binol-based hydroxyl-thioether ligand precursors, copies of ${ }^{31} \mathrm{P}\{1 \mathrm{H}\},{ }^{1} \mathrm{H}$, and ${ }^{13} \mathrm{C}\{1 \mathrm{H}\}$ NMR spectra, enantiomeric excess determination and characterization details of hydrogenated products, calculated energies for all TSs for ligands $\mathbf{L} 1$ and $\mathbf{L} 2$ and of the most stable TSs for L4, NCI plot description for the most stable TSs with ligand L1, and computationally postulated catalytic cycle (PDF)

\section{AUTHOR INFORMATION}

\section{Corresponding Authors}

Maria Besora - Universitat Rovira i Virgili. Departament de Química Física i Inorgànica, Tarragona 43007, Spain; ○ orcid.org/0000-0002-6656-5827; Email: maria.besora@ urv.cat

Montserrat Diéguez - Universitat Rovira $i$ Virgili. Departament de Química Física i Inorgànica, Tarragona 43007, Spain; (o orcid.org/0000-0002-8450-0656; Email: montserrat.dieguez@urv.cat

\section{Authors}

Jorge Faiges - Universitat Rovira $i$ Virgili. Departament de Química Física i Inorgànica, Tarragona 43007, Spain

Carlota Borràs - Universitat Rovira $i$ Virgili. Departament de Química Física i Inorgànica, Tarragona 43007, Spain

Isidro M. Pastor - Organic Chemistry Department and Instituto de Síntesis Orgánica (ISO), University of Alicante, Alicante 03080, Spain; 이이.org/0000-0002-8271-0641

Oscar Pàmies - Universitat Rovira $i$ Virgili. Departament de Química Física i Inorgànica, Tarragona 43007, Spain; (1) orcid.org/0000-0002-2352-8508

Complete contact information is available at:

https://pubs.acs.org/10.1021/acs.organomet.1c00450

\section{Notes}

The authors declare no competing financial interest.

\section{ACKNOWLEDGMENTS}

We gratefully acknowledge financial support from the Spanish Ministry of Science and Innovation (PID2019-104904GB-I00, PGC2018-100780-B-I00, and PGC2018-096616-B-I00), European Regional Development Fund (AEI/FEDER, UE), the Catalan Government (2017SGR1472), and the University of Alicante (VOGROB-316FI). M.B. also thanks the URV for generous support.

\section{REFERENCES}

(1) ((a)) Jacobsen, E. N.; Pfaltz, A.; Yamamoto, H. Eds. Comprehensive Asymmetric Catalysis; Springer-Verlag: Berlin, 1999. ((b)) Ojima, I. Ed. Catalytic Asymmetric Synthesis; 3rd Edn, John Wiley \& Sons, Inc.: Hoboken, 2010. ((c)) Blaser, H.-U.; Federsel, H.J. Eds. Asymmetric Catalysis in Industrial Scale: Challenges, Approaches and Solutions; 2nd Edn; Wiley: Weinheim, 2010. ((d)) Noyori, R. Asymmetric Catalysis in Organic Synthesis; Wiley: New York, 1994.

(2) (a) Busacca, C. A.; Fandrick, D. R.; Song, J. J.; Senanayake, C. H. The Growing Impact of Catalysis in the Pharmaceutical Industry. Adv. Synth. Catal. 2011, 353, 1825-1864. (b) Ager, D. J.; de Vries, A. H. M.; de Vries, J. G. Asymmetric homogeneous hydrogenations at scale. Chem. Soc. Rev. 2012, 41, 3340-3380. (c) Blaser, H.-U. Looking Back on 35 Years of Industrial Catalysis. Chimia 2015, 69, 393-406.

(3) ((a)) Genêt, J. P. In Modern Reduction Methods; Andersson, P. G.; Munslow, I. J. Eds; Wiley-VCH: Weinheim, 2008, pp. 3-38. (b) Tang, W.; Zhang, X. New Chiral Phosphorus Ligands for Enantioselective Hydrogenation. Chem. Rev. 2003, 103, 3029-3070. ((c)) Chi, Y.; Tang, W.; Zhang, X. In Modern Rhodium-Catalyzed Organic Reactions; Evans, P. A. Ed; Wiley-VCH: Weinheim, 2005, pp. 1-31. ((d)) Kitamura, M.; Noyori, R. in Ruthenium in Organic Synthesis; Murahashi, S.-I. Ed.; Wiley-VCH: Weinheim, 2005, pp. 3- 
52. (e) Weiner, B.; Szymanski, W.; Janssen, D. B.; Minnaard, A. J.; Feringa, B. L. Recent Advances in the Catalytic Asymmetric Synthesis of Beta-amino Acids. Chem. Soc. Rev. 2010, 39, 1656-1691. (f) Xie, J.H.; Zhu, S.-F.; Zhou, Q.-L. Transition Metal-Catalyzed Enantioselective Hydrogenation of Enamines and Imines. Chem. Rev. 2011, 111, 1713-1760. (g) Etayo, P.; Vidal-Ferran, A. Rhodium-catalysed asymmetric hydrogenation as a valuable synthetic tool for the preparation of chiral drugs. Chem. Soc. Rev. 2013, 42, 728-754.

(4) (a) Cui, X.; Burgess, K. Catalytic Homogeneous Asymmetric Hydrogenations of Largely Unfunctionalized Alkenes. Chem. Rev. 2005, 105, 3272-3296. (b) Roseblade, S. J.; Pfaltz, A. IridiumCatalyzed Asymmetric Hydrogenation of Olefins. Acc. Chem. Res. 2007, 40, 1402-1411. (c) Woodmansee, D. H.; Pfaltz, A. Asymmetric Hydrogenation of Alkenes Lacking Coordinating Groups. Chem. Commun. 2011, 47, 7912-7916. (d) Zhu, Y.; Burgess, K. Filling Gaps in Asymmetric Hydrogenation Methods for Acyclic Stereocontrol: Application to Chirons for Polyketide-Derived Natural Products. Acc. Chem. Res. 2012, 45, 1623-1636. (e) Verendel, J. J.; Pàmies, O.; Diéguez, M.; Andersson, P. G. Asymmetric Hydrogenation of Olefins Using Chiral Crabtree-type Catalysts: Scope and Limitations. Chem. Rev. 2014, 114, 2130-2169. (f) Margarita, C.; Andersson, P. G. Evolution and Prospects of the Asymmetric Hydrogenation of Unfunctionalized Olefins. J. Am. Chem. Soc. 2017, 139, 1346-1356.

(5) (a) Yoon, T. P.; Jacobsen, E. N. Privileged chiral catalysts. Science 2003, 299, 1691-1693. ((b)) Zhou, Q.-L. Ed. Privileged Chiral Ligands and Catalysts; Wiley-VCH: Weinheim, 2011. ((c)) Diéguez, M. Ed., Chiral ligands. Evolution of ligand libraries for asymmetric catalysis; CRC Press: Boca Raton, 2021.

(6) (a) Coll, M.; Pàmies, O.; Diéguez, M. Thioether-phosphite: New Ligands for the Highly Enantioselective Ir-catalyzed Hydrogenation of Minimally Functionalized Olefins. Chem. Commun. 2011, 47, 92159217. (b) Coll, M.; Pàmies, O.; Diéguez, M. A Modular Furanoside Thioether-Phosphite/Phosphinite/ Phosphine Ligand Library for Asymmetric Iridium-Catalyzed Hydrogenation of Minimally Functionalized Olefins: Scope and Limitations. Adv. Synth. Catal. 2013, 355, 143-160. (c) Margalef, J.; Caldentey, X.; Karlsson, E. A.; Coll, M.; Mazuela, J.; Pàmies, O.; Diéguez, M.; Pericàs, M. A. A Theoretically-Guided Optimization of a New Family of Modular P,S-Ligands for Iridium-Catalyzed Hydrogenation of Minimally Functionalized Olefins. Chem. - Eur. J. 2014, 20, 12201-12214. (d) Borràs, C.; Biosca, M.; Pàmies, O.; Diéguez, M. Iridium-Catalyzed Asymmetric Hydrogenation with Simple Cyclohexane-Based P/S Ligands: In Situ HP-NMR and DFT Calculations for the Characterization of Reaction Intermediates. Organometallics 2015, 34, 53215334. (e) Biosca, M.; Coll, M.; Lagarde, F.; Brémond, E.; Routaboul, L.; Manoury, E.; Pàmies, O.; Poli, R.; Diéguez, M. Chiral Ferrocenebased P,S Ligands for Ir-catalyzed Hydrogenation of Minimally Functionalized Olefins. Scope and Limitations. Tetrahedron 2016, 72, 2623-2631. (f) de la Cruz-Sánchez, P.; Faiges, J.; Mazloomi, Z.; Borràs, C.; Biosca, M.; Pàmies, O.; Diéguez, M. Ir/ThioetherCarbene, -Phosphinite, and -Phosphite Complexes for Asymmetric Hydrogenation. A Case for Comparison. Organometallics 2019, 38, 4193-4205. (g) Margalef, J.; Pàmies, O.; Pericàs, M. A.; Diéguez, M. Evolution of phosphorus-thioether ligands for asymmetric catalysis. Chem. Commun. 2020, 56, 10795-10808.

(7) (a)) Gladiali, S.; Dore, A.; Fabbri, D. Novel heterobidentate ligands for asymmetric catalysis: Synthesis and rhodium-catalysed reactions of S-alkyl (R)-2-diphenylphosphino-1,1'-binaphthyl-2'-thiol. Tetrahedron: Asymmetry 1994, 5, 1143-1146. (b) Gladiali, S.; Medici, S.; Pirri, G.; Pulacchini, S.; Fabbri, D. BINAPS - An axially chiral P,Sheterodonor ligand for asymmetric catalysis based on binaphthalene backbone. Can. J. Chem. 2001, 79, 670-678. (c) Kang, J. H.; Yu, S. H.; Kim, J. I.; Cho, H. G. Catalytic Asymmetric Allylic Alkylation with A Novel PS Bidentate Ligand. Bull. Korean Chem. Soc. 1995, 16, 439443. (d) Zhang, W.; Shi, M. Axially chiral P,S-heterodonor ligands with a binaphthalene framework for palladium-catalyzed asymmetric allylic substitutions: experimental investigation on the reversal of enantioselectivity between different alkyl groups on sulfur atom. Tetrahedron: Asymmetry 2004, 15, 3467-3476. (e) Hoshi, T.; Sasaki,
K.; Sato, S.; Ishii, Y.; Suzuki, T.; Hagiwara, H. Highly enantioselective Pd-catalyzed allylic alkylation of indoles using sulfur-MOP ligand. Org. Lett. 2011, 13, 932-935.

(8) (a) Brandt, P.; Hedberg, C.; Andersson, P. G. New Mechanistic Insights into the Iridium-Phosphanooxazoline-Catalyzed Hydrogenation of Unfunctionalized Olefins: A DFT and Kinetic Study. Chem. - Eur. J. 2003, 9, 339-347. (b) Fan, Y.; Cui, X.; Burgess, K.; Hall, M. B. Electronic effects steer the mechanism of asymmetric hydrogenations of unfunctionalized aryl-substituted alkenes. J. Am. Chem. Soc. 2004, 126, 16688-16689. (c) Cui, X.; Fan, Y.; Hall, M. B.; Burgess, K. Mechanistic Insights into Iridium-Catalyzed Asymmetric Hydrogenation of Dienes. Chem. - Eur. J. 2005, 11, 6859-6868. (d) Church, T. L.; Rasmussen, T.; Andersson, P. G. Enantioselectivity in the Iridium-Catalyzed Hydrogenation of Unfunctionalized Olefins. Organometallics 2010, 29, 6769-6781. (e) Hopmann, K. H.; Bayer, A. On the mechanism of iridium-catalyzed asymmetric hydrogenation of imines and alkenes: A theoretical study. Organometallics 2011, 30, 2483-2497. (f) Mazuela, J.; Norrby, P.-O.; Andersson, P. G.; Pàmies, O.; Diéguez, M. Pyranoside Phosphite-Oxazoline Ligands for the Highly Versatile and Enantioselective Ir-Catalyzed Hydrogenation of Minimally Functionalized Olefins. A Combined Theoretical and Experimental Study. J. Am. Chem. Soc. 2011, 133, 13634-13645. (g) Gruber, S.; Pfaltz, A. Asymmetric hydrogenation with iridium C, $\mathrm{N}$ and $\mathrm{N}, \mathrm{P}$ ligand complexes: characterization of dihydride intermediates with a coordinated alkene. Angew. Chem., Int. Ed. 2014, 53, 1896-1900.

(9) (a) Aguado-Ullate, S.; Saureu, S.; Guasch, L.; Carbó, J. J. Theoretical Studies of Asymmetric Hydroformylation Using the Rh$(\mathrm{R}, \mathrm{S})$-BINAPHOS Catalyst-Origin of Coordination Preferences and Stereoinduction. Chem. - Eur. J. 2012, 18, 995-1005. (b) AguadoUllate, S.; Urbano-Cuadrado, M.; Villalba, I.; Pires, E.; García, J. I.; Bo, C.; Carbó, J. J. Predicting the Enantioselectivity of the CopperCatalysed Cyclopropanation of Alkenes by Using Quantitative Quadrant-Diagram Representations of the Catalysts. Chem. - Eur. J. 2012, 18, 14026-14036.

(10) Please note that upon changing the olefin, the mechanism or the lowest energy conformer could change.

(11) For key references on the asymmetric hydrogenation of enol phosphinates and alkenylboronic esters, see: (a) Cheruku, P.; Gohil, S.; Andersson, P. G. Asymmetric hydrogenation of enol phosphinates by iridium catalysts having N, P ligands. Org. Lett. 2007, 9, 16591661. (b) Cheruku, P.; Diesen, J.; Andersson, P. G. Asymmetric Hydrogenation of Di and Trisubstituted Enol Phosphinates with N,PLigated Iridium Complexes. J. Am. Chem. Soc. 2008, 130, 5595-5599. (c) Paptchikhine, A.; Cheruku, P.; Engman, M.; Andersson, P. G. Iridium-catalyzed enantioselective hydrogenation of vinyl boronates. Chem. Commun. 2009, 5996-5998. (d) Ganič, A.; Pfaltz, A. IridiumCatalyzed Enantioselective Hydrogenation of Alkenylboronic Esters. Chem. - Eur. J. 2012, 18, 6724-6728.

(12) For key references on the asymmetric hydrogenation of $\alpha, \beta$ disubstituted unsaturated ketones, lactones and lactams, see: (a) Tian, F.; Yao, D.; Liu, Y.; Xie, F.; Zhang, W. Iridium-Catalyzed Highly Enantioselective Hydrogenation of Exocyclic $\alpha, \beta$-Unsaturated Carbonyl Compounds. Adv. Synth. Catal. 2010, 352, 1841-1845. (b) Rageot, D.; Woodmansee, D. H.; Pugin, B.; Pfaltz, A. ProlineBased P,O Ligand/Iridium Complexes as Highly Selective Catalysts: Asymmetric Hydrogenation of Trisubstituted Alkenes. Angew. Chem., Int. Ed. 2011, 50, 9598-9601. (c) Xi, J. Q.; Quan, X.; Andersson, P. G. Highly Enantioselective Iridium-Catalyzed Hydrogenation of $\alpha, \beta$ Unsaturated Esters. Chem. - Eur. J. 2012, 18, 10609-10616. (d) Woodmansee, D. H.; Müller, M. A.; Tröndlin, L.; Hörmann, E.; Pfaltz, A. Asymmetric Hydrogenation of $\alpha, \beta$-Unsaturated Carboxylic Esters with Chiral Iridium N, P Ligand Complexes. Chem. - Eur. J. 2012, 18, 13780-13786. (e) Liu, X.; Han, Z.; Wang, Z.; Ding, K. SpinPhox/Iridium (I)-Catalyzed Asymmetric Hydrogenation of Cyclic $\alpha$-Alkylidene Carbonyl Compounds. Angew. Chem., Int. Ed. 2014, 53, 1978-1982. (f) Lu, S. M.; Bolm, C. Highly Enantioselective Synthesis of Optically Active Ketones by IridiumCatalyzed Asymmetric Hydrogenation. Angew. Chem., Int. Ed. 2008, 
47, 8920-8923. (g) Lu, W.-J.; Chen, Y.-W.; Hou, X.-L. IridiumCatalyzed Highly Enantioselective Hydrogenation of the C-C Bond of $\alpha, \beta$-Unsaturated Ketones. Angew. Chem., Int. Ed. 2008, 47, 1013310136. (h) Shang, J.; Han, Z.; Li, Y.; Wang, Z.; Ding, K. Highly enantioselective asymmetric hydrogenation of (E)- $\beta, \beta$-disubstituted $\alpha, \beta$-unsaturated Weinreb amides catalyzed by Ir (I) complexes of SpinPhox ligands. Chem. Commun. 2012, 48, 5172-5174. (i) Biosca, M.; Pàmies, O.; Diéguez, M. Giving a Second Chance to Ir/ Sulfoximine-Based Catalysts for the Asymmetric Hydrogenation of Olefins Containing Poorly Coordinative Groups. J. Org. Chem. 2019, 84, 8259-8266. (j) Xia, J.; Nie, Y.; Yang, G.; Liu, Y.; Gridnev, I. D.; Zhang, W. Ir-Catalyzed Asymmetric Hydrogenation of $\alpha$-Alkylidene $\beta$-Lactams and Cyclobutanones. Chin. J. Chem. 2018, 36, 612-618.

(13) See for instance: (a) Duggan, M. E.; Naylor-Olsen, A. M.; Perkins, J. J.; Anderson, P. S.; Chang, C. T.-C.; Cook, J. J.; Gould, R. J.; Ihle, N. C.; Hartman, G. D.; Lynch, J. J.; Lynch, R. J.; Manno, P. D.; Schaffer, L. W.; Smith, R. L. Non-peptide fibrinogen receptor antagonists. 7. Design and synthesis of a potent, orally active fibrinogen receptor antagonist. J. Med. Chem. 1995, 38, 3332-3341. (b) Schneider, U.; Pannecoucke, X.; Quirion, J. C. Regio- and Diastereoselective Synthesis of a Primary $\beta$-Azidoalcohol via Stereoselective Epoxidation of a Highly Functionalised di-o,o'-Substituted Styrene: Toward a New Total Synthesis of (-)-Quinocarcin. Synlett 2005, 1853-1856. (c) Ghosh, A. K.; Kumaragurubaran, N.; Hong, L.; Kulkarni, S. S.; Xu, X.; Chang, W.; Weerasena, V.; Turner, R.; Koelsch, G.; Bilcer, G.; Tang, J. Design, Synthesis, and X-ray Structure of Potent Memapsin 2 ( $\beta$-Secretase) Inhibitors with Isophthalamide Derivatives as the $\mathrm{P}_{2}-\mathrm{P}_{3}$-Ligands. J. Med. Chem. 2007, 50, 2399-2407. (d) Saudan, L. A. Hydrogenation processes in the synthesis of perfumery ingredients. Acc. Chem. Res. 2007, 40, 1309-1319.

(14) Pàmies, O.; Andersson, P. G.; Diéguez, M. Asymmetric Hydrogenation of Minimally Functionalised Terminal Olefins: An Alternative Sustainable and Direct Strategy for Preparing Enantioenriched Hydrocarbons. Chem. - Eur. J. 2010, 16, 14232-14240.

(15) The isomerization most likely proceeds via formation of Ir- $\pi$ allyl intermediates or of an stable carbocation at the double bond at the terminal position, see: (a) Perry, M. C.; Cui, X.; Powell, M. T.; Hou, D.-R.; Reibenspies, J. H.; Burgess, K. Optically Active Iridium Imidazol-2-ylidene-oxazoline Complexes: Preparation and Use in Asymmetric Hydrogenation of Arylalkenes. J. Am. Chem. Soc. 2003, 125, 113-123. (b) Brown, J. M.; Derome, A. E.; Hughes, G. D.; Monaghan, P. K. Homogeneous Hydrogenation With Iridium Complexes. Evidence for Polyhydride Intermediates in the Reduction of $\alpha$-Pinene. Aust. J. Chem. 1992, 45, 143-153.

(16) (a) Pharm, D. Q.; Nogid, A. Rotigotine Transdermal System for the Treatment of Parkinson's Disease. Clin. Ther. 2008, 30, 813824. (b) Astier, B.; Lambás Señas, L.; Soulière, F.; Schmitt, P.; Urbain, N.; Rentero, N.; Bert, L.; Denoroy, L.; Renaud, B.; Lesourd, M.; Muñoz, C.; Chouvet, G. In Vivo Comparison of Two 5-HT1A Receptors Agonists Alnespirone (S-20499) and Buspirone on Locus Coeruleus Neuronal Activity. Eur. J. Pharmacol. 2003, 459, 17-26. (c) Ross, S. B.; Thorberg, S.-O.; Jerning, E.; Mohell, N.; Stenfors, C.; Wallsten, C.; Milchert, I. G.; Ojteg, G. A. Robalzotan (NAD-299), a Novel Selective 5-HT1A Receptor Antagonist. CNS Drug Rev. 1999, $5,213-232$.

(17) For selected examples: (a) Renaud, J. L.; Dupau, P.; Hay, A.-E.; Guingouain, M.; Dixneouf, P. H.; Bruneau, C. Ruthenium-Catalysed Enantioselective Hydrogenation of Trisubstituted Enamides Derived from 2-Tetralone and 3-Chromanone: Influence of Substitution on the Amide Arm and the Aromatic Ring. Adv. Synth. Catal. 2003, 345, 230-238. (b) Hoen, R.; van den Berg, M.; Bernsmann, H.; Minnaard, A. J.; de Vries, J. G.; Feringa, B. L. Catechol-Based Phosphoramidites: A New Class of Chiral Ligands for Rhodium-Catalyzed Asymmetric Hydrogenations. Org. Lett. 2004, 6, 1433-1436. (c)) Jiang, X.-B.; Lefort, L.; Goudriaan, P. E.; de Vries, A. H.; van Leeuwen, P. W.; Reek, J. N. Screening of a Supramolecular Catalyst Library in the Search for Selective Catalysts for the Asymmetric Hydrogenation of a Difficult Enamide Substrate. Angew. Chem., Int. Ed. 2006, 45, 12231227. (d) Sandee, A. J.; van der Burg, A. M.; Reek, J. N. H.
UREAphos: Supramolecular Bidentate Ligands for Asymmetric Hydrogenation. Chem. Commun. 2007, 864-866. (e) Revés, M.; Ferrer, C.; León, T.; Doran, S.; Etayo, P.; Vidal-Ferran, A.; Riera, A.; Verdaguer, X. Primary and Secondary Aminophosphines as Novel PStereogenic Building Blocks for Ligand Synthesis. Angew. Chem., Int. Ed. 2010, 49, 9452-9455. (f) Wu, Z.; Ayad, T.; RatovelomananaVidal, V. Efficient Enantioselective Synthesis of 3-Aminochroman Derivatives Through Ruthenium-Synphos Catalyzed Asymmetric Hydrogenation. Org. Lett. 2011, 13, 3782-3785. (g) Pignataro, L.; Boghi, M.; Civera, M.; Carboni, S.; Piarulli, U.; Gennari, C. RhodiumCatalyzed Asymmetric Hydrogenation of Olefins with PhthalaPhos, a New Class of Chiral Supramolecular Ligands. Chem. - Eur. J. 2012, 18, 1383-1400. (h) Frank, D. J.; Franzke, A.; Pfaltz, A. Asymmetric Hydrogenation Using Rhodium Complexes Generated from Mixtures of Monodentate Neutral and Anionic Phosphorus Ligands. Chem. Eur. J. 2013, 19, 2405-2415. (i) Bravo, M. J.; Ceder, R. M.; Muller, G.; Rocamora, M. New Enantiopure P,P-Bidentate Bis(diamidophosphite) Ligands. Application in Asymmetric RhodiumCatalyzed Hydrogenation. Organometallics 2013, 32, 2632-2642. (j) Arribas, I.; Rubio, M.; Kleman, P.; Pizzano, A. Rhodium Phosphine-Phosphite Catalysts in the Hydrogenation of Challenging N-(3,4-dihydronaphthalen-2-yl) Amide Derivatives. J. Org. Chem. 2013, 78, 3997-4005. (k) Liu, G.; Liu, X.; Cai, Z.; Jiao, G.; Xu, G.; Tang, W. Design of Phosphorus Ligands with Deep Chiral Pockets: Practical Synthesis of Chiral $\beta$-Arylamines by Asymmetric Hydrogenation. Angew. Chem., Int. Ed. 2013, 52, 4235-4238.

(18) Salom, E.; Orgué, S.; Riera, A.; Verdaguer, X. Highly Enantioselective Iridium-Catalyzed Hydrogenation of Cyclic Enamides. Angew. Chem., Int. Ed. 2016, 55, 7988-7992.

(19) (a) Magre, M.; Pàmies, O.; Diéguez, M. PHOX-Based Phosphite-Oxazoline Ligands for the Enantioselective Ir-Catalyzed Hydrogenation of Cyclic $\beta$-Enamides. ACS Catal. 2016, 6, 51865190. (b) Margalef, J.; Pàmies, O.; Diéguez, M. Phosphite-Thiother Ligands Derived from Carbohydrates allow the Enantioswitchable Hydrogenation of Cyclic $\beta$-Enamides by using either $\mathrm{Rh}$ or $\mathrm{Ir}$ Catalysts. Chem. - Eur. J. 2018, 23, 813-822. (c) Biosca, M.; Magre, M.; Pàmies, O.; Diéguez, M. Asymmetric Hydrogenation of Disubstituted, Trisubstituted, and Tetrasubstituted Minimally Functionalized Olefins and Cyclic $\beta$-Enamides with Easily Accessible Ir-P, Oxazoline Catalysts. ACS Catal. 2018, 8, 10316-10320.

(20) Buisman, G. J. H.; Kamer, P. C. J.; van Leeuwen, P. W. N. M. Rhodium Catalysed Asymmetric Hydroformylation with Chiral Diphosphite Ligands. Tetrahedron: Asymmetry 1993, 4, 1625-1634.

(21) Frisch, M. J.; Trucks, G. W.; Schlegel, H. B.; Scuseria, G. E.; Robb, M. A.; Cheeseman, J. R.; Scalmani, G.; Barone, V.; Petersson, G. A.; Nakatsuji, H.; Li, X.; Caricato, M.; Marenich, A.; Bloino, J.; Janesko, B. G.; Gomperts, R.; Mennucci, B.; Hratchian, H. P.; Ortiz, J. V.; Izmaylov, A. F.; Sonnenberg, J. L.; Williams-Young, D.; Ding, F.; Lipparini, F.; Egidi, F.; Goings, J.; Peng, B.; Petrone, A.; Henderson, T.; Ranasinghe, D.; Zakrzewski, V. G.; Gao, J.; Rega, N.; Zheng, G.; Liang, W.; Hada, M.; Ehara, M.; Toyota, K.; Fukuda, R.; Hasegawa, J.; Ishida, M.; Nakajima, T.; Honda, Y.; Kitao, O.; Nakai, H.; Vreven, T.; Throssell, K.; Montgomery, J. A., Jr.; Peralta, J. E.; Ogliaro, F.; Bearpark, M.; Heyd, J. J.; Brothers, E.; Kudin, K. N.; Staroverov, V. N.; Keith, T.; Kobayashi, R.; Normand, J.; Raghavachari, K.; Rendell, A.; Burant, J. C.; Iyengar, S. S.; Tomasi, J.; Cossi, M.; Millam, J. M.; Klene, M.; Adamo, C.; Cammi, R.; Ochterski, J. W.; Martin, R. L.; Morokuma, K.; Farkas, O.; Foresman, J. B.; Fox, D. J. Gaussian 09, Revision A.02; Gaussian, Inc.: Wallingford CT, 2016.

(22) (a) Becke, A. D. Density-functional thermochemistry. III. The role of exact Exchange. J. Chem. Phys. 1993, 98, 5648-5652. (b) Stephens, P. J.; Devlin, F. J.; Chabalowski, C. F.; Frisch, M. J. Ab Initio Calculation of Vibrational Absorption and Circular Dichroism Spectra Using Density Functional Force Fields. J. Phys. Chem. 1994, 98, 11623-11627.

(23) Grimme, S.; Antony, J.; Ehrlich, S.; Krieg, H. A consistent and accurate $a b$ initio parametrization of density functional dispersion correction (DFT-D) for the 94 elements H-Pu. J. Chem. Phys. 2010, 132, 154104. 
(24) (a) Ditchfield, R.; Hehre, W. J.; Pople, J. A. Self-Consistent Molecular-Orbital Methods. IX. An Extended Gaussian-Type Basis for Molecular-Orbital Studies of Organic Molecules. J. Chem. Phys. 1971, 54, 724. (b) Hehre, W. J.; Ditchfield, R.; Pople, J. A. Self-Consistent Molecular Orbital Methods. XII. Further Extensions of GaussianType Basis Sets for Use in Molecular Orbital Studies of Organic Molecules. J. Chem. Phys. 1972, 56, 2257. (c) Hariharan, P. C.; Pople, J. A. The influence of polarization functions on molecular orbital hydrogenation energies. Theor. Chem. Acc. 1973, 28, 213-222. (d) Hariharan, P. C.; Pople, J. A. Accuracy of $\mathrm{AH}_{\mathrm{n}}$ equilibrium geometries by single determinant molecular orbital theory. Mol. Phys. 1974, 27, 209-214. (e)) Francl, M. M.; Pietro, W. J.; Hehre, W. J.; Binkley, J. S.; DeFrees, D. J.; Pople, J. A.; Gordon, M. S. Selfconsistent molecular orbital methods. XXIII. A polarization-type basis set for second-row elements. J. Chem. Phys. 1982, 77, 3654. (f) Binning, R. C., Jr.; Curtiss, L. A. Compact contracted basis sets for third-row atoms: Ga-Kr. J. Comput. Chem. 1990, 11, 1206-1216. (g) Blaudeau, J.-P.; McGrath, M. P.; Curtiss, L. A.; Radom, L. Extension of Gaussian-2 (G2) theory to molecules containing thirdrow atoms K and Ca. J. Chem. Phys. 1997, 107, 5016.

(25) (a) Hay, P. J.; Wadt, W. R. Ab initio effective core potentials for molecular calculations. Potentials for the transition metal atoms Sc to Hg. J. Chem. Phys. 1985, 82, 270-283. (b) Hay, P. J.; Wadt, W. R. Ab initio effective core potentials for molecular calculations. Potentials for $\mathrm{K}$ to $\mathrm{Au}$ including the outermost core orbitals. J. Chem. Phys. 1985, 82, 299-310.

(26) Tomasi, J.; Mennucci, B.; Cammi, R. Quantum Mechanical Continuum Solvation Models. Chem. Rev. 2005, 105, 2999-3094.

(27) (a) Perdew, J. P.; Burke, K.; Ernzerhof, M. Generalized Gradient Approximation Made Simple. Phys. Rev. Lett. 1996, 77, 3865-3868. (b) Perdew, J. P.; Burke, K.; Ernzerhof, M. Generalized Gradient Approximation Made Simple. Phys. Rev. Lett. 1997, 78, $1396-1396$.

(28) Grimme, S. Semiempirical GGA-type density functional constructed with a long-range dispersion correction. J. Comput. Chem. 2006, 27, 1787-1799.

(29) (a) McLean, A. D.; Chandler, G. S. Contracted Gaussian basis sets for molecular calculations. I. Second row atoms, $\mathrm{Z}=11-18$. $J$. Chem. Phys. 1980, 72, 5639-5648. (b) Khrisnan, R.; Binkley, J. S.; Seeger, R.; Pople, J. A. Self-consistent molecular orbital methods. XX. A basis set for correlated wave functions. J. Chem. Phys. 1980, 72, 650-654.

(30) Hopmann, K. H. How Accurate is DFT for Iridium-Mediated Chemistry? Organometallics 2016, 35, 3795-3807.

(31) Grimme, S. Supramolecular Binding Thermodynamics by Dispersion-Corrected Density Functional Theory. Chem. - Eur. J. 2012, 18, 9955-9964.

(32) Luchini, G.; Alegre-Requena, J. V.; Funes-Ardoiz, I.; Paton, R. S. GoodVibes: automated thermochemistry for heterogeneous computational chemistry data. F1000Research 2020, 9, 291.

(33) Margalef, J. Screening of modular and readily available ligand libraries for $\mathrm{C}-\mathrm{X}(\mathrm{X}=\mathrm{H}, \mathrm{C}, \mathrm{N}$ and $\mathrm{O})$ bond forming reactions. The use of DFT studies for catalysts optimization. PhD Thesis. Universitat Rovira i Virgili: Tarragona, Spain, 2016. 